NBER WORKING PAPER SERIES

\title{
THE HOUSING MARKET IMPACT OF \\ STATE-LEVEL ANTI-DISCRIMINATION LAWS, 1960-1970
}

\author{
William J. Collins \\ Working Paper 9562 \\ http://www.nber.org/papers/w9562 \\ NATIONAL BUREAU OF ECONOMIC RESEARCH \\ 1050 Massachusetts Avenue \\ Cambridge, MA 02138 \\ March 2003
}

I am grateful for suggestions from Jeremy Atack, Leemore Dafny, Michael Greenstone, Robert Margo, William Rodgers, and Jacob Vigdor, as well as from participants in the University of Chicago's Empirical Economics Workshop, Vanderbilt University's Economics Lunch Seminar, and an AEA session at the ASSA Meetings in 2003. Brett Austin, Timothy Dore, Daniel Ramsey, and Stephanie Schacht provided excellent research assistance. Research support was provided by the National Science Foundation (SES 0095943), the National Bureau of Economic Research (National Fellowship, 2001-2002), and Harvard University's Du Bois Institute (Non-Resident Fellowship, 2001-2002). Views expressed herein are those of the author and not necessarily those of the National Bureau of Economic Research, the National Science Foundation, or the Du Bois Institute.

(C)2003 by William J. Collins. All rights reserved. Short sections of text not to exceed two paragraphs, may be quoted without explicit permission provided that full credit including Cnotice, is given to the source. 
The Housing Market Impact of State-Level Anti-Discrimination Laws, 1960-1970

William J. Collins

NBER Working Paper No. 9562

March 2003

JEL No. R3, K31, N42

\section{$\underline{\text { ABSTRACT }}$}

This paper measures the housing market impact of state-level anti-discrimination laws in the 1960s using household-level and census-tract data. State-level "fair-housing" laws attempted to bar discrimination on the basis of race, religion, and national origin in the sale, rental, and financing of housing, and they were the direct antecedents of the federal Fair Housing Act of 1968. Their influence on the housing market outcomes of African Americans has not been assessed in previous work by economists, but policy variation across states during the 1960s provides an opportunity to pursue such estimates. During the 1960s, blacks' housing market outcomes improved relative to whites', and the proportion of exclusively white census tracts declined markedly. But I find little evidence that the fairhousing laws contributed to those changes. Rather, the bulk of the evidence indicates that the laws' effects on blacks' housing market outcomes, on residential segregation, and on the value of property in predominantly nonwhite neighborhoods were negligible.

William J. Collins

Department of Economics

Box 351819-B

Vanderbilt University

Nashville, TN 37235

william.collins@vanderbilt.edu 


\section{Introduction}

At mid-century, an array of barriers inhibited African Americans' residential mobility, including racially restrictive covenants among white property owners, biased lending practices of banks and government institutions, strong social norms against selling or renting property to blacks outside established black neighborhoods, and harassment of blacks seeking residence in otherwise white neighborhoods (Myrdal 1944, Weaver 1948, Abrams 1955, Sugrue 1996, Meyer 2000, Brooks 2002). Since then, the potentially adverse effects of housing discrimination on blacks' accumulation of wealth through housing equity and on blacks' access to high quality schools, jobs, and public goods have been widely discussed (Kain 1968, Oliver and Shapiro 1995, Yinger 2001). A related literature has sought to understand the apparent connection between residential segregation, in part a legacy of housing market discrimination (Kain and Quigley 1975), and a variety of adverse socioeconomic outcomes (Massey and Denton 1993, Cutler and Glaeser 1997, Collins and Margo 2000).

Given these concerns, it is not surprising that dismantling housing market discrimination has been among the top priorities of civil rights groups and urban policymakers for decades. Starting in 1959, states began implementing "fair-housing" laws to curb discriminatory practices by sellers, renters, real estate agents, builders, and lenders. By the time the federal government passed the Fair Housing Act of 1968, 22 states, covering 57 percent of the total U.S. population and 41 percent of the black population had already passed fair-housing legislation, usually with more extensive coverage and stronger enforcement mechanisms than in the federal act. Although fair-housing laws are commonly placed among the Civil Rights Movement's central legislative achievements, their impact on blacks' housing market outcomes has not been examined directly and empirically. ${ }^{1}$ Of course, the laws did not completely undermine discriminatory practices nor the residential patterns that such practices had promoted. The more relevant questions concern how much headway the laws made on discriminatory practices and segregation, and especially, whether black families improved their housing situation

${ }^{1}$ Audit studies of housing market interactions have revealed ongoing discriminatory behavior (see Yinger 1998), and other studies have discussed the shortcomings of the federal Fair Housing Act of 1968 at length, but the extent to which any changes in discriminatory behavior associated with fair-housing laws have translated into better housing market outcomes for protected groups remains unmeasured. 
because of the laws' implementation.

Understanding the state fair-housing laws' impact is important for two reasons. First, residential segregation and housing market discrimination are still serious concerns for policymakers. Debates about these issues should be informed about how anti-discrimination policies worked, or did not work, in the recent past. The state laws provide a valuable, but neglected, source of evidence. Second, the economics literature on the contribution of Civil Rights-era legislation to blacks' economic progress is heavily weighted towards federal labor market legislation, with special emphasis on the South. Allocating some attention to housing legislation at the state level, primarily outside the South, will contribute to a more balanced and accurate assessment of the Civil Rights Movement's economic impact.

It has been noted that during the 1960s, blacks' average housing market outcomes improved relative to whites', at least according to broad and commonly referenced measures (Bianchi, Farley, and Spain 1982, Collins and Margo 2001, 2003). Among household heads, the racial gap in home ownership rates fell from about 27 to 25 percentage points. Among home owners, the value of blackowned housing increased from about 53 to 60 percent of white-owned housing. Even after controlling for household characteristics (such as income and education), the racial gaps in ownership and value narrowed between 1960 and 1970. Also, in the 1960s middle- and upper-class black families moved to suburban neighborhoods in larger numbers than ever before, and the average level of residential segregation within cities began to decline around 1970 (Cutler, Glaeser, and Vigdor 1999). All of this leaves the door open for a significant fair-housing policy effect, but it is far from a direct evaluation of the hypothesis that fair-housing laws helped improve blacks' housing market outcomes.

How could the fair-housing laws have contributed to improvement in blacks' housing outcomes? As discussed in more detail below, the laws were intended to lower barriers to blacks' entry into predominantly white neighborhoods and new housing developments, and to curb discriminatory treatment of blacks seeking mortgages, thereby lowering the effective cost of housing and expanding minorities' set of housing opportunities. If this mechanism actually worked as intended, then one would expect blacks to increase their housing consumption relative to whites, ceteris paribus. 
One might also expect to see more racial integration in neighborhoods, though in theory, this need not follow. Of course, given that the laws' enforcement mechanisms were far from draconian and that discriminatory biases in housing markets were deeply rooted, it is possible that the laws had no detectable effect whatsoever.

In 1963, the National Committee Against Discrimination in Housing, an umbrella organization for several religious, labor, and civil rights groups, claimed that fair housing laws "are proving to be an increasingly important factor in the movement of minority-group families into residential areas which formerly were closed to them." But already, the organization noted that "civil rights groups have become increasingly dissatisfied with the rate of progress under the laws" (Sept.-Oct. 1963, pp. 1-2). The extent to which there was progress under the laws, and due to the laws, remains an unanswered, empirical question.

I review the history of fair-housing laws in section 2 and outline the economics of their potential impact in section 3. In section 4, I discuss the empirical strategy for analyzing household-level data. In short, the measurement of fair-housing effects is facilitated by variation in anti-discrimination policies across states during the 1960s. The results of the household data analysis are discussed in section 5 . An alternative empirical perspective that explores census-tract data is developed in section 6.

\section{A Brief History of Fair-Housing Laws}

State and local governments incrementally adopted nondiscriminatory standards for public housing starting in the late 1930s. The application of anti-discrimination policy to the private housing market, however, was among the Civil Rights Movement's least popular initiatives among whites, and as a result, fair-housing legislation lagged years behind fair-employment and public accommodations laws (Lockard 1968). Even in 1970, after the passage of the federal Fair Housing Act, less than 30 percent of northern whites favored fair-housing laws according to a National Opinion Research Center survey (Greeley and Sheatsley 1971, p. 18). On one level, this reflected whites' concerns about crime, property values, schools, and interracial social contact. On another level, it reflected the rhetorical strength of the argument that the government ought not infringe on perceived private property rights, 
particularly with respect to homes (NCDH, Sept.-Oct. 1963, p. 4).

Nevertheless, as the Great Migration of blacks to central-city neighborhoods continued through the 1950s, and as the Civil Rights Movement gained momentum, fair-housing initiatives rose toward the top of the Movement's legislative agenda. The National Committee Against Discrimination in Housing (NCDH) was organized in 1950 to help advocate anti-discrimination measures and to report on their legislative progress. Seven years later, New York City adopted the nation's first fair-housing ordinance which served as a model for several of the subsequent state laws and was itself based on existing fairemployment statutes (Lockard 1968, p. 118). While granting exceptions for the rental of rooms in or attached to owner-occupied homes (the "Mrs. Murphy rule"), the ordinance (as amended in 1962) stated that:

"no owner, . . . real estate broker, ... or other person having the right to sell, rent, lease, ... or otherwise dispose of a housing accommodation ... shall refuse to sell, rent, lease ... or otherwise deny or withhold from any person or group of persons such housing accommodations, or represent that such housing accommodations are not available for inspection, when in fact they are so available, because of the race, color, religion, national origin or ancestry of such persons" (Housing and Home Finance Agency 1964, p. 287).

It also barred discrimination in the terms of sale or rental, advertisements expressing discriminatory preferences, and discrimination by banks and lending institutions. Finally, it outlined a procedure for handling complaints and enforcing the policy.

The state fair-housing statutes initially had varying degrees of coverage. Table 1 reports the timing of each state's initial adoption and later extension of fair-housing laws up to 1968. Almost all states included a Mrs. Murphy rule. More importantly, some states also exempted activities surrounding the sale or rental of owner-occupied single-family homes. Others, listed in column 2, allowed the owner-occupiers of homes to discriminate while simultaneously prohibiting discriminatory acts by real-estate brokers, advertisers, lenders, and builders. By 1968, as listed in column 3, several states had converged to a standard that covered virtually all sales and rentals (except those by Mrs. Murphy). In general, these state laws contained stronger enforcement mechanisms than the federal legislation passed in that year (discussed below). 
Following procedures established to enforce the earlier fair-employment laws, the administrative agencies charged with enforcing the fair-housing laws did so, for the most part, by responding to individual complaints rather than by seeking out discriminatory practices. When presented with a viable complaint (i.e., within the law's coverage), the agency would conduct an investigation. If evidence of discrimination was found, the agency's representatives would attempt to persuade the discriminatory party to comply with the law. If the discriminatory party refused to cooperate, a public hearing could be held, a cease and desist order and/or fine could be issued, court proceedings could be undertaken, and (if appropriate) a real estate agent's license could be suspended. Of course, all of this would take time, and households attempting to move might not have been willing or able to wait for redress. Beyond their enforcement role, fair-housing agencies often undertook broad educational campaigns and offered advice to community leaders and housing industry participants regarding residential integration. ${ }^{2}$

The effectiveness of this approach in dealing with housing market discrimination or, more to the point, in improving blacks' housing market outcomes, is unclear a priori. The anti-discrimination measures were weak in the sense that the agencies' first step was always to seek "conciliation" rather than punishment. Thus, even if caught, there was no immediate penalty and perhaps little incentive to adjust discriminatory policies until confronted by the agency. Even so, the passage of the laws and the threat of sanctions against resistant builders, lenders, or real estate agents might have facilitated conciliation procedures once initiated, might have modified discriminatory behavior immediately (rendering complaints unnecessary), and might have provided a convenient excuse for those who wished to do business with blacks but felt constrained by community norms. ${ }^{3}$ Moreover, the speed with which some neighborhoods "tipped" from white to black might have amplified spillover effects

2 For example, Lockard (1968, pp. 126-127) reports that the New York agency, with some assistance from the FHA, coordinated a non-discriminatory agreement among apartment builders who were otherwise locked in a prisoner's dilemma. That is, absent the coordination (and potential sanctions) provided by the agency, the builders articulated an incentive to defect from the non-discriminatory principle.

${ }^{3}$ See Donohue and Heckman (1991) on the effective "excuse" that the Civil Rights Act of 1964 might have provided southern employers. 
from enforcement efforts. Finally, it is possible that the passage of the law itself or the state agency's educational campaigns contributed to changing social norms regarding discrimination and residential segregation. As suggested above, whether the fair-housing laws actually contributed to the observed relative improvement in blacks' housing market outcomes remains an unanswered empirical question.

The federal Fair Housing Act of 1968 initially exempted privately owned, single-family housing. The policy's coverage was extended over the next two years, but the Department of Housing and Urban Development's (HUD) enforcement powers remained severely circumscribed (Yinger 1999). Informal, clandestine efforts at persuasion were allowed, nothing more, not even the threat of a public hearing. If persuasion failed, the complainant was then free to sue for an injunction in federal court. The federal law also specified that a state with its own fair-housing law had initial jurisdiction over any complaints originating there. The empirics below proceed as though the 1968 Fair Housing Act had a negligible (or an even-across-states) effect on African Americans' relative housing market outcomes by the time of the 1970 Census. ${ }^{4}$

\section{Discrimination and the Potential Impact of Fair-Housing Laws}

In theory, the potential impact of a fair-housing law depends on how discriminatory attitudes and institutions influenced the housing market equilibrium prior to the law's implementation. Discrimination could either raise or depress the relative price of housing for blacks, and therefore has indeterminate effects on observable housing market outcomes (e.g., ownership rates, crowding, quality of structure, et cetera) (Kain and Quigley 1975; Courant 1978; Cutler, Glaeser, and Vigdor 1999). In the simplest formulation, white and black areas may form distinct submarkets within which prices (normalized to homogeneous units) are determined by demand and supply. A stable boundary or division of housing between blacks and whites would require that the effective price facing members of

\footnotetext{
${ }^{4}$ Though the literature on the federal Civil Rights Act of 1964 has demonstrated that inferring a law's impact from caseload data is problematic, it is at least worth noting that in 1970 there were 1,008 federal fair-housing investigations undertaken, of which only 89 were classified as "successfully conciliated" by the year's end (HUD 1970, p. 85). The Fair Housing Amendments Act of 1988 substantially broadened enforcement powers (Yinger 2001).
} 
each group on the other side of the boundary is greater than the price on their own side. ${ }^{5}$ That is, for whites, $P_{W}$ is less than or equal to $P_{B}+C_{W}$; and for blacks, $P_{B}$ is less than or equal to $P_{W}+C_{B}$, where $\mathrm{P}_{\mathrm{W}}$ and $\mathrm{P}_{\mathrm{B}}$ are prices in the white and black submarkets respectively, and $\mathrm{C}_{\mathrm{W}}$ and $\mathrm{C}_{\mathrm{B}}$ are additional costs associated with buying or renting housing from a member of the other group. These additional costs are broadly construed, and may include changes in distance to work, harassment by disgruntled neighbors, search and transaction costs (perhaps including a bonus to homeowners of the other group to sell against the wishes of their neighbors), and lost utility associated with being surrounded by one's own racial group. If either of these inequality conditions did not hold, then members of one group would buy or rent housing previously owned or rented by members of the other, and the racial distribution of housing would shift until a new equilibrium is reached.

In practice, for most of the twentieth century, the economics and history literatures suggest that the constraint on blacks was binding. That is, from the outset of the Great Migration during World War I, black residents in metropolitan areas pressed against the boundaries of circumscribed neighborhoods; these neighborhoods expanded when and where the internal pressure was strong enough to outweigh countervailing pressure from whites (i.e., whenever $\mathrm{P}_{\mathrm{B}}>\mathrm{P}_{\mathrm{W}}+\mathrm{C}_{\mathrm{B}}$ ). ${ }^{6}$ In this scenario, black neighborhoods would expand just to the point where the price gap is offset by the extra costs of crossing the existing racial boundary $\left(\mathrm{P}_{\mathrm{B}}=\mathrm{P}_{\mathrm{W}}+\mathrm{C}_{\mathrm{B}}\right)$. Along these lines, Kain and Quigley wrote in 1975 that "most types of housing are more expensive inside the ghetto, and that a premium is required to shift bundles to the ghetto submarket" (p. 68). ${ }^{7}$ In general, whites did not seek to move into

${ }^{5}$ This model's characterization is similar in some ways to that in Kain and Quigley (1975). The model does not really depend on having geographically distinct white and black "areas" and a "boundary" in between, though the text's language reflects the prevalence of residential segregation. All that is necessary is that there are higher transaction costs (broadly defined) when buying from someone (or near someone) of a different race. For a discussion of models in which the "boundary" idea is central, in that whites' utility increases with distance from blacks, see Courant and Yinger (1977).

${ }^{6}$ In discussing the formation of the black ghetto in Harlem in the 1920s, Osofsky argued that rents were relatively high despite "deplorable" living conditions because of "the unprecedented demand created by heavy Negro migration and settlement within a restricted geographical area" (1966, p. 136). As suggested in the model sketched above, the boundaries of the ghetto expanded in response (p. 127).

${ }^{7}$ Cutler, Glaeser, and Vigdor argue that through mid-century, discriminatory practices "made blacks pay relatively more for housing in more segregated cities than they otherwise would have" (1997, p. 487). Becker (1957) also suggests that blacks in Chicago paid more than whites for equivalent housing 
established black areas; after all, the quality-adjusted price was apparently higher and the "additional costs" are presumed positive (on net). Rather, as described in detail by Abrams (1955) and Meyer (2000), white homeowners, real estate agents, and financial institutions collectively imposed a high cost on blacks attempting to move into white neighborhoods. In a search model for housing, Courant (1978) demonstrated it is not necessary for all whites in a given neighborhood to collude against potential black residents to generate an equilibrium in which whites enjoy lower housing costs than blacks and in which there is persistent racial segregation. Rather, as the proportion of white sellers who are averse to dealing with blacks rises, so do the expected search costs faced by blacks considering buying from whites. Only if the price gap between white and black neighborhoods exceeds a certain threshold level (a level that rises with the proportion of discriminatory white sellers) will blacks attempt to buy housing from whites.

Taking these characterizations as a starting point, and supposing that the total supply of housing is initially fixed, an equilibrium where $P_{B}=P_{W}+C_{B}$ implies that blacks consume less housing than they would in the no-discrimination equilibrium, and whites consume more. Ceteris paribus, the implementation of effective anti-discrimination laws could have lowered the costs imposed on blacks trying to buy or rent property. If so, then the racial price gap would narrow and the quantity of housing consumed by blacks would increase.

One might suppose that the margin of extension of the suburbs is determined by the price of existing white housing relative to the price of new housing construction. In this period, new suburban housing was consumed almost entirely by whites, so this appears to be a reasonable addition to the model. ${ }^{8}$ In this scenario, if the implementation of a fair-housing law puts upward pressure on the price

bundles. Also see King and Mieszkowski (1973) on this issue.

8 In 1959, the Pennsylvania Governor's Committee on Discrimination in Housing reported that "Negro Pennsylvanians have been almost totally excluded from the many hundreds of thousands of new homes built by private enterprise since World War II" (p. 8). Likewise, the U.S. Commission on Civil Rights notes (without attribution) that "As late as 1959, it was estimated that less than 2 percent of the FHA-insured housing built in the post-war housing boom had been available to minorities" (1973, p. 5). It is not clear exactly what "excluded" and "available" mean, but the point is clear - new suburban housing was essentially white housing. One could suppose that there was also a price at which new black suburban housing developments should have come into being. Based on anecdotal evidence, one could argue that the price of new housing construction for blacks was higher than for whites because of barriers 
of white housing, as suggested above, then the housing stock can simply expand in response. If the price of new construction $\left(\mathrm{P}_{\mathrm{NEW}}\right)$ is exogenously fixed, then the supply expands until there is no longer upward pressure on $\mathrm{P}_{\mathrm{W}}$. Ceteris paribus, the price and quantity of white housing would return to their original levels, and by implication, the quantity of black housing would increase by the amount of the supply's expansion. Thus, even though the new housing is actually consumed by whites, the quantity of housing consumed by blacks increases through a "filtering" process.

So far, the analysis has not attempted to distinguish between rental and owner-occupied housing. It is possible that the application of anti-discrimination measures, particularly to mortgage lenders and insurers, lowered the price of owner-occupied housing for blacks (relative to renting), thereby encouraging more home ownership. Likewise, if the initial stock of housing available for blacks included a low proportion of owner-occupied units relative to the stock of housing initially owned by whites, then the black home ownership rate might have increased as units were transferred from whites to blacks. ${ }^{9}$

This simple model does not allow for heterogeneity among households, but it is certainly plausible that different age, income, or education groups responded to or were affected by the laws in different ways (hypotheses that will be investigated below). For example, influential work in the literature on the deterioration of central-city black neighborhoods cites the loss of relatively welleducated blacks to suburban neighborhoods after the passage of fair-housing legislation (Wilson 1987). Along these lines, a 1963 publication from the National Committee Against Discrimination in Housing claimed that "the chief beneficiaries thus far [have been] nonwhites of middle-class status" (Sept.-Oct. 1963, p. 1). In the context of this section's model, which does not attempt to address potentially positive spillovers from high human capital neighbors, movement away from central-city neighborhoods would lower housing demand in those neighborhoods, thereby lowering housing prices, alleviating crowding, and allowing increased housing consumption for those who remained, at least in the short to

to financing and land acquisition.

${ }^{9}$ Of course, owner-occupied housing can be transformed into rental housing, and often was, and so the categories for the housing stock are not truly fixed. 
medium run during which the central-city housing stock is assumed fixed. ${ }^{10}$

\section{Empirical Strategy: Household Data}

Although I am unaware of any previous econometric effort to identify the impact of state fairhousing laws, there is a literature that measures the impact of state-level fair-employment laws (Landes 1968, Stigler 1973, Heckman 1976, Neumark and Stock 2001, Collins 2003). The early fairemployment studies examined state-level aggregate data, but the more recent efforts, like this paper, have used micro-level data in difference-in-difference-in-difference (DDD) frameworks, where comparisons are made between states, between races, and over time, while controlling for a variety of household-level covariates as well as state, race, and time fixed effects.

The simple model outlined above suggests that, ceteris paribus, blacks' consumption of housing should have increased by more between 1960 and 1970 in states that had extensive fair-housing laws than in other states, if the laws actually worked as intended. To gauge housing consumption, the census collects and consistently reports information on a handful of basic housing characteristics, including whether the unit is owner-occupied, the number of rooms, the number of bathrooms, the age of the building, whether it is detached or attached, its estimated value or current rental price, and (though sometimes compromised for confidentiality purposes) whether it is in a central city, suburb, or neither. For now, the empirics focus on observable housing characteristics, postponing the study of property values and rental rates to section 6 where census tract data allow more informative comparisons. ${ }^{11}$

The model collapsed all housing into quality-adjusted housing units, and in that spirit, I created a hedonic index based on the valuation of observable housing characteristics in 1960 (separately for renters and owners, and for blacks and whites). Specifically, for each race category, I regressed the

\footnotetext{
${ }^{10}$ Some discussion of urban renewal programs that may have lowered the net housing stock in central city neighborhoods is provided below.

${ }^{11}$ Section 3's model predicts that the price of housing for blacks should fall, but because the property value information in the household-level census data will also reflect unobserved changes in quality, movements in observed prices are difficult to interpret. For example, an effective law might lower the "true" price of housing but simultaneously allow blacks to move to better neighborhoods (which would tend to raise the observed price). A better set of comparisons, offered in section 6, focus on changes in the relative price of housing in predominantly black neighborhoods.
} 
$\log$ of rent or value on a series of indicators for the number of rooms, number of bathrooms, age of unit, and whether it was a detached unit. Then, given the regression coefficients, I assigned each housing unit (for both 1960 and 1970) a predicted hedonic value. ${ }^{12}$ The idea is to isolate changes in the quantity of housing consumed by collapsing an array of housing characteristics, weighted by the regression coefficients, into a single index. More transparently, but less comprehensively, I examine several dimensions of housing quality independently (e.g., rooms, bathrooms, building age, etc.). I also look for fair-housing effects on the likelihood of home ownership and the size of households.

I start with a fairly broad sample from the 1960 and 1970 Integrated Public Use Microdata Series (IPUMS, Ruggles and Sobek 1997), including all native-born male and female household heads who were not in school, not living on a farm, and were from 20 to 59 years old. Then, in case the laws affected subgroups of the population differently, I narrow the focus to relatively young household heads (under 40), to those who have recently changed residences (within five years), or to those with at least 12 years of education. In general, when assessing changes in housing characteristics, I examine samples of renters and owners separately because the laws differed in some ways across rental and owner-occupied housing, and because the characteristics of rental and owner-occupied housing are so different. Selection out of rental and into owner-occupied housing, as well as selection into headship, are legitimate concerns even with controls for household and household head characteristics, and so I start by examining the laws' influence on household size and home ownership rates.

As mentioned above, the fair-housing estimates are formed using difference-in-difference-indifference (DDD) regression frameworks. Essentially, DDD estimation compares blacks' housing in states with relatively extensive fair housing laws ("experimental states”) to blacks' housing in states with narrow or no fair housing laws ("'non-experimental states"), relative to whites' outcomes within each state-group (a second difference), before and after the laws' adoption (a third difference). When helpful, I also refer to difference-in-difference (DD) estimates that compare the magnitudes of changes in blacks' outcomes in experimental and non-experimental states (without differencing by whites' outcomes). The regressions control for several relevant household characteristics, including the log of

\footnotetext{
${ }^{12}$ I repeated the exercise when the comparison group of states changed.
} 
real family income (and a dummy for topcoded income), the number of persons in the household (quadratic), and the number of children in the household (a series of dummies). The regressions also control for the head's years of education (quadratic), age (quartic), marital status, veteran status, sex, and whether the head moved from another state within the last five years. ${ }^{13}$

The choice of "experimental"and "non-experimental" states is a key aspect of any DDD strategy. The identifying assumption is that there were no unobserved contemporaneous shocks or trends that affected the outcomes of blacks relative to whites in experimental states relative to nonexperimental states. All other shocks and trends should be effectively differenced out by design or captured by the household characteristic variables. The next subsection offers some supporting evidence for the choice of state-groups, and I check the robustness of the basic results using alternative comparison groups, population subsamples, and specifications.

The basic DDD regression set up is:

$$
\begin{gathered}
\mathrm{H}_{\mathrm{ijt}}=\alpha+\beta_{1} \mathrm{X}_{\mathrm{ijt}}+\beta_{2} \text { Black }_{\mathrm{ijt}}+\beta_{3} \mathrm{FH}_{\mathrm{j}}+\beta_{4} \text { Year }_{\mathrm{t}} \\
+\beta_{5}\left(\text { Black }_{\mathrm{ijt}} \times \mathrm{FH}_{\mathrm{j}}\right)+\beta_{6}\left(\text { Black }_{\mathrm{ijt}} \times \text { Year }_{\mathrm{t}}\right)+\beta_{7}\left(\mathrm{FH}_{\mathrm{j}} \times \mathrm{Year}_{\mathrm{t}}\right)+\beta_{8}\left(\text { Black }_{\mathrm{ijt}} \times \mathrm{FH}_{\mathrm{j}} \times \mathrm{Year}_{\mathrm{t}}\right) .
\end{gathered}
$$

$H$ is a housing market outcome variable; $i$ indexes households, $j$ indexes the two groups of states (experimental and non-experimental), and $t$ indexes two census years. $X$ is the vector of household characteristics listed above. Black is a dummy variable equal to one for blacks; $F H$ is a dummy variable equal to one for states that adopted relatively strong fair-housing laws before 1965; and Year is a dummy variable equal to one for the later census year in the comparison. In an additional specification, I also include the proportion of each state's population that was black and that proportion's interaction with the black dummy variable to control for the influence of changes in the relative size of the black population on blacks' relative housing market outcomes. In another specification, I add state and state-year dummies to control for unobserved state-level shocks that affect blacks and whites alike. Difference-in-difference (DD) regressions for blacks only (or whites only) are similar in form but, of course, do not require dummies for race or interactions between race

\footnotetext{
${ }^{13}$ One might also like to include a metropolitan residence dummy variable, but in 1960 and 1970 many households are assigned indeterminate status for confidentiality reasons. Rather than discard the observations, I proceeded without the metro status variable.
} 
and other variables.

In this basic regression, $\beta_{2}$ reflects time-invariant and state-invariant differences between blacks and whites. $\beta_{3}$ reflects time-invariant and race-invariant differences between strong fair-housing states and weak fair-housing states. $\beta_{4}$ captures race-invariant and state-invariant changes over time. $\beta_{5}$ captures time-invariant differences between blacks and whites in strong fair-housing states relative to weak fair-housing states. $\beta_{6}$ reflects state-invariant changes in blacks' housing market outcomes relative to whites'. $\beta_{7}$ reflects race-invariant changes over time in the strong fair-housing states relative to weak fair-housing states. Finally, $\beta_{8}$ measures the change in blacks' outcomes relative to whites' outcomes in strong fair-housing states relative to weak fair-housing states. This is the regression estimate of the fair-housing effect.

\section{Choosing State-Groups for Comparison}

The interpretation of the $\beta_{8}$ coefficient as a "fair-housing effect" is most tenable when the groups of states being compared are economically and socially similar, and therefore subject to common, though perhaps unobserved, shocks and trends. ${ }^{14}$ This consideration guides the selection of states for comparison here. In the case of fair-housing laws, the selection is complicated by differences in the extent of the state laws' coverage, as well as by the presence of municipal ordinances. ${ }^{15}$ For the experimental state-group, I selected states with policies that covered (nearly) all owner-occupied and rental housing by 1965: Colorado, Connecticut, Indiana, Massachusetts, Michigan, New York, and Rhode Island.

For comparison, I formed two sets of non-experimental states: "non-experimental group A" may be a closer match with the experimental states based on economic and political characteristics, but “non-experimental group B” has a sharper differentiation of policy. Group A consists of Pennsylvania,

${ }^{14}$ See Besley and Case (2000) or Meyer (1995) for more extensive discussions of the opportunities and pitfalls of DDD methodology.

${ }^{15}$ Because the 1960 census microdata for households do not report city codes, it is impossible to identify municipalities; rather, work must proceed at the state-level while keeping underlying and potentially confounding municipal policies in mind. 
Ohio, Illinois, and Wisconsin all of which had fair-housing initiatives that were narrower in coverage than those of the experimental states. Pennsylvania passed an early fair housing law (1961) that omitted owner-occupied, one- and two-family buildings, as did the city ordinances in Philadelphia, Pittsburgh, and Erie. Ohio's 1965 law also omitted owner-occupied, one- and two-family buildings; its major cities did not pass ordinances; and smaller cities (e.g., Akron and Toledo) that did pass ordinances often saw them struck down by referendum or in court (NCDH 1966). Illinois did not pass a private fair housing law, and Chicago's ordinance (1963) and Governor Otto Kerner's executive order (made in 1966 but suspended by injunction) applied only to real estate agents (Landye and Vanecko 1968). Wisconsin's 1965 fair housing law exempted single-family owner-occupied housing units and owneroccupied apartment buildings with less than five units.

The distinction between the policies pursued by the experimental states and group A of the nonexperimental states is not as sharp as one would like, especially in rental markets; hence the motivation for forming a second comparison group. Non-experimental group B consists of Delaware, Kansas, Maryland, Missouri, and West Virginia, all of which had weak or no state fair-housing laws applying to private housing. The tradeoff is that group B is not as geographically proximate nor as economically and politically similar to the experimental states as Group A is, and so the identifying assumption regarding unobserved shocks and trends may be more at risk.

Table 2 reports a series of relevant state characteristics for the three groups of states. The figures for 1960 indicate how similar the state-groups were at the beginning of the period under study in terms of both population averages (for black proportion of population, ownership rates, persons per room, proportion of households in at least 30-year old housing units, proportion of households with two or more bathrooms, family income, and votes for George Wallace in 1968's presidential election) and black-white disparities. For the most part, the 1960 characteristics are similar across the state-groups, though as expected, non-experimental group B is less similar to the experimental states than group A is. The differences that stand out are that proportionally fewer households resided in owner-occupied housing in the experimental states than in the other groups (58 versus 63 percent), the black-white disparity in the likelihood of residing in 30-year old housing is smaller in the experimental states (23 
versus 27 and 29 percent), and non-experimental group B had lower average family income and less “older" housing.

The votes-for-George-Wallace variable has been used elsewhere to gauge discriminatory sentiment (Bergman and Lyle 1971, Heckman 1976), and a somewhat lower proportion of voters in the experimental states ( 7 percent) voted for Wallace than in the non-experimental states ( 9 and 12 percent in groups $\mathrm{A}$ and $\mathrm{B}$ respectively). If that is a reasonable gauge, one might hypothesize that blacks' acquisition of housing was more actively impeded in more discriminatory states during the 1960s, and that therefore the empirics could have a built-in bias that favors finding a positive fairhousing effect. This hypothesis is worth keeping in mind, however, in the model outlined above, when $\mathrm{P}_{\mathrm{B}}=\mathrm{P}_{\mathrm{W}}+\mathrm{C}_{\mathrm{B}}$, different levels of discriminatory sentiment would have a "level effect" but not a "growth effect" on blacks' housing outcomes, and there is no evidence that discriminatory sentiment changed by more in one state-group than in the others.

If discriminatory sentiment had changed by more in the states that passed comprehensive laws than in those that did not pass laws, then $\beta_{8}$ would capture the influence of both the laws and the differential trends in sentiment. Though it is impossible to rule out this possibility altogether, it is worth noting that nationally, there was not a dramatic change in sentiment regarding housing market discrimination during the 1960s. In 1963 and 1970, the National Opinion Research Center charted adult whites' reaction to the following statement: "White people have a right to keep Negroes out of their neighborhoods if they want to, and Negroes should respect that right." In 1963, about 43 percent of whites disagreed with the statement; in 1970, about 50 percent did (Greeley and Sheatsley 1971, p. 14). Unfortunately, the responses are not reported by state, but it seems that the scope for differential changes in public attitudes regarding housing discrimination across the set of states used in this paper is rather narrow. ${ }^{16}$ Greeley and Sheatsley do report trends for a broader measure of discriminatory sentiment by South versus Non-South, and it appears that even across very dissimilar regions the changes in sentiment were of similar magnitude (p. 15). Again, if there is a bias, it is likely to raise the

16 Along these lines, Meyer (1995) points out that changes in state laws may provide useful quasi-experimental frameworks when the change in policy is abrupt relative to the change in underlying public sentiment. 
$\beta_{8}$ coefficient by bundling the effect of differential changes in discriminatory sentiment together with the effect of the laws.

A variation on the "differential change in sentiment" hypothesis is that blacks' attitudes towards housing discrimination and segregation may have shifted further in experimental states than in others, independent of the laws. There is a surprising scarcity of survey information for blacks during this period, let alone data that are disaggregated by region or state, but the existing evidence does not suggest that there were large changes in attitudes towards residential choice during the 1960s: nearly all blacks surveyed in 1964 and 1970 agreed that blacks "have a right to live wherever they can afford to, just like anybody else". In a "general segregation" question with more room for upward movement, 78 percent of blacks surveyed favored desegregation in both 1964 and 1970 (Schuman et al. 1997, p. 242).

Of course, for $\beta_{8}$ to measure the fair-housing effect accurately, the laws must be exogenous to changes in the racial gap in housing market outcomes. Collins (2002) explores the political economy of fair-housing law adoption at length. That paper's empirical findings, and the historical literature from which the paper draws (e.g., Lockard 1968), emphasize differences in political, ethnic, and economic characteristics across non-southern states, rather than changes in racial disparities in housing market variables within states, in explaining the timing of policy adoption. However, the size of the black population does appear to have influenced the timing of fair-housing adoption, could have had an influence on blacks' relative housing market outcomes, and changed non-trivially over time in several states. With this in mind, I check the sensitivity of the basic regression results to the inclusion of each state's black proportion of the population (in year t), interacted with the black dummy variable to capture the differential effect of black population growth on blacks' relative housing outcomes.

Examining the data for pre-existing trends is somewhat more difficult than checking the levels in 1960 because the 1950 IPUMS sample does not include housing information. Relying on the published census volumes for housing information, I report 1950-1960 trends at the bottom of table 2. The stategroups, particularly the experimental states and non-experimental group A, appear to have been trending similarly in terms of the black proportion of the population, the proportion of owner-occupied 
housing units, the proportion of housing units built during the 1950s, and the average level of log family income. The racial gap in nominal family income did widen by more in the experimental states than elsewhere during the 1950s, but all the regressions below will control for family income. Thus, while the 1950 to 1960 trends and the 1960 levels cannot completely rule out the possibility of confounding, unobserved shocks during the 1960s, table 2 does support the notion that the state-groups are reasonable bases for comparison.

\section{Household Data Results}

\section{Ownership and Household Size}

Most of the DDD regressions are run separately for renters and owners, primarily to see whether the laws' effects differed across types of housing. Some caution is necessary here, however, because selection into home ownership is not random. To a large extent, the differencing strategy and the controls for observable $\mathrm{X}$-variables (such as income, marital status, age and so on) should mitigate selection issues. But if there is a race-specific change in the nature of selection into home ownership that differs across state groups, perhaps due to the fair-housing laws themselves, then the interpretation of the results obtained using only owners or only renters could be biased.

Table 3 offers some direct evidence on this hypothesis by reporting DDD probit coefficients for ownership status. ${ }^{17}$ The idea is see whether black households increased their likelihood of owning a home, relative to whites, by more in the experimental states than in the control states, conditional on observable household characteristics (though results are similar without controls for X -variables). Using non-experimental group A, there is no evidence that the fair-housing laws facilitated movement into the ownership category. Using non-experimental group $\mathrm{B}$, the coefficients are positive but statistically weak in most specifications.

${ }^{17}$ Coefficients for the probit regressions in tables 3, 4, and 6 represent the change in probability associated with switching the triple-interaction dummy from 0 to 1 (for all observations) when all other variables (including dummies) are set at their sample means. In principle, these probit coefficients cannot be directly interpreted as the magnitude of the treatment effects. But in the relatively few cases when the probit coefficients approach conventional levels of statistical significance, OLS analogues, whose interpretation is straightforward, are close in magnitude. 
I also check whether the formation of households was influenced by the laws, perhaps by facilitating the establishment of households by younger adults. In table 3, household size is treated as a dependent variable in the DDD framework. Again, there is no evidence that the fair-housing laws were associated with significant relative changes. These results go some distance towards alleviating concerns about unobserved selection into home ownership. Moreover, appendix table A1 confirms that the basic results reported below are unchanged when owners and renters are pooled into a single sample.

\section{Housing Characteristics}

Table 4 reports $\beta_{8}$ coefficients for regressions in which the dependent variable is one of a variety of housing characteristics. Summary statistics for the housing characteristics are reported in appendix table A2. The first two columns report DDD coefficients for the probability of having two or more complete bathrooms (z-statistics are in parentheses). Among owners, the coefficients are weakly negative; among renters, the coefficients are weakly positive. The coefficients do not approach high levels of statistical significance in either case.

The third and fourth columns report DDD coefficients for living in housing that was more than 30 years old (the topcode in the 1960 and 1970 census). The coefficients are again statistically weak in general, and when not weak (as for young renters), are positive. To check whether the results are driven by white flight to new housing developments in response to the fair-housing laws, it is straightforward to make DD comparisons among whites only. That is, did whites in the experimental states increase their likelihood of residing in newer housing (under 30 year old) by more than whites elsewhere? By this metric, there is no evidence that whites in fair-housing states had a larger decline in the likelihood of residing in relatively old housing than whites elsewhere. The same is true in DD comparisons among blacks only - there are no statistically significant differences across the stategroups.

The most statistically durable, and somewhat puzzling, results appear in the columns for the number of rooms. Of course, the number of rooms is a crude measure of housing unit size, and so its 
interpretation is not without ambiguity. But by this standard, relative to whites, blacks in fair housing states appear to have lost ground over the decade compared to blacks in the non-experimental states. Although not always strongly significant, the negative coefficients persist for both renters and owners, for group A and group B of non-experimental states, for each population subsample, for specifications including the black proportion of each state's population (and its interaction with the race dummy variable) and for specification including state and state-year dummies. The coefficients are non-trivial in magnitude, but they are far from large: 0.2 rooms is about 4 percent of the mean endowment of rooms. The proximate causes of this result are straightforward. For example, among owners, blacks and whites in the non-experimental states (groups A and B) and whites in the experimental states all increased their average number of rooms during the 1960s, but blacks in the experimental state-group did not. The underlying economic explanation remains unclear, though four plausible hypotheses suggest themselves.

The first hypothesis is directly related to the selection issues discussed above. Perhaps the fairhousing laws facilitated movement of relatively wealthy black renters into the owner-occupied category, and perhaps within the owner-occupied category, they were less affluent than others. In other words, the fair-housing laws might have driven selection into the ownership sample which simultaneously tended to lower the average wealth and the number of rooms for both black renters and owners. The regressions control for income, education, and age, all of which should be strongly correlated with wealth, but wealth itself remains unobserved. Table 3, however, suggested that the laws were not associated with significant differential selection into the ownership category. Furthermore, when renters and owners are pooled into one sample so that selection into the owner category cannot lead to a change in sample composition, the negative $\beta_{8}$ coefficient for the number of rooms is not undermined (appendix table A1). ${ }^{18}$

A second hypothesis is that fair housing laws alleviated supply constraints faced by black families, allowing the formation of smaller households that happened to inhabit fewer rooms on average.

${ }^{18}$ The coefficient is $-0.27(\mathrm{t}$-stat $=7.23)$ when using non-experimental group $\mathrm{A}$ and all households. The coefficient is $-0.18(\mathrm{t}$-stat $=3.47)$ when using non-experimental group B and all households. See table A2. 
Again, there is very little support for this conjecture. The regressions of table 4 already control for household size directly; and in table 3, where household size is treated as a dependent variable, there is no evidence that the fair-housing laws were associated with significant relative changes.

A third hypothesis is that whites in fair-housing states responded to the laws by moving to relatively large suburban homes. In this case, blacks in fair-housing states might appear to have fared poorly relative to whites in the DDD framework, even as they benefitted from the laws by gaining access to better housing than before. In fact, a DD estimate using a white-only sample suggests that white households in the experimental states did increase their number of rooms relative to whites elsewhere, but only by about 0.05 rooms $(\mathrm{t}$-stat $=4.57)$, and white renters did not. In a similar blackonly DD framework, there is no support for the notion for that blacks in fair-housing states increased their number of rooms relative to other blacks: black owners and renters both lost ground in the fairhousing states relative to blacks in other states.

A fourth hypothesis, more difficult to assess directly than the previous three, is that other policies and programs, such as urban renewal and public housing, were undertaken with differing degrees of intensity across the state-groups and that they had differential racial impacts that confound the DDD estimates. According to Weicher (1972) urban renewal programs, particularly their slum clearance aspect, tended to reduce the stock of low-cost housing and make relatively poor residents, particularly black poor residents, worse off (also see Staples 1970 and White 1980). The 1970 HUD Statistical Yearbook reports cumulative funding (1950-1970) for urban renewal projects in each state. Per capita disbursements for "urban renewal projects" suggest that the experimental states (\$29.7 per 1970 capita) and non-experimental group A (\$28.5 per 1970 capita) were similar, but that nonexperimental group B received considerably less funding (\$19.5 per 1970 capita). The funding disparity gap narrows, though not by much, if calculated relative to each state's urban population: $\$ 37.3$ in the experimental states, $\$ 37.8$ in non-experimental group A, and \$29.0 in non-experimental group B. Of course, the urban renewal funding figures are not precise indicators of the extent of slum clearance, or more to the point, of the extent to which the projects reduced the overall supply of housing for blacks relative to whites. But on the basis of the funding figures, it would be difficult to argue that the 
experimental states were substantially more aggressive in their renewal efforts than non-experimental group A. Morever, if significantly more of the older housing stock in predominantly black neighborhoods had been demolished in the experimental states than in the non-experimental states, then one would expect a DD estimate (among blacks) of the relative change in the likelihood of residing in older housing to be negative. But it is not. More systematic investigation of urban renewal's impact on racial disparities in housing markets is certainly warranted, but a comprehensive assessment, state by state, extends far beyond the bounds of this paper. ${ }^{19}$

The negative result on the number of rooms is interesting, but its economic significance should not be overstated. First, the coefficient represents an economically small difference. Second, as noted below, the "rooms" component's influence on the overall hedonic housing values is offset by other factors.

\section{Hedonic Index}

The hedonic index is a composite estimate of housing consumption in 1960 and 1970, formed using race-specific valuations of various property characteristics in 1960 as weights (thereby avoiding the issue of endogenous price changes during the decade). Table 5 reports DDD estimates of the effect of fair-housing laws on the hedonic index. Among owners, there is no evidence that the fair-housing laws facilitated improvements in blacks' housing; the coefficients are consistently negative and insignificantly different from zero. Among renters, the results suggest a more positive influence. In comparison with both non-experimental groups, the racial gap among renters in fair-housing states appears to have improved slightly relative to the racial gap among renters in non-fair-housing states (by

\footnotetext{
${ }^{19}$ Public housing and urban renewal efforts often went hand-in-hand. The HUD Yearbook
} reports the number of low-rent public housing units in 1970 by state (but unfortunately, not for earlier years). The experimental states and non-experimental group A are nearly identical in terms of units per capita (0.00388 and 0.00387), whereas group B has fewer units (0.00252). In terms of public housing units inhabited by blacks per black capita, a more substantial difference emerges between the experimental states and group A. The experimental states had 0.0177 black-inhabited units per black capita, whereas group A had 0.0234 , and group B had 0.0158. It is possible, therefore, that public housing alleviated more housing market pressure for blacks in non-experimental group A than in the experimental states (or in group B), but even among urban blacks, public housing was a relatively small portion of the housing market, and the difference between state-groups was smaller yet. 
about 2 to 4 percent). When the hedonic results for renters are decomposed, it appears that the ageof-building, bathrooms, and attachment variables all contribute to the result.

This finding may seem somewhat puzzling given the results in table 4 which suggested that there were no significant positive effects on the quantities of various housing components, and in fact, that there was a slight relative decline in the number of rooms per household in fair-housing states. In this regard, it is important to note that the hedonic indices weight housing characteristics differently by race, and so changes in the hedonic indices reflect a combination of changes in quantities and racial differences in the weights assigned to those quantities. Of all the results presented in this paper, this finding is most suggestive of a positive fair-housing effect on blacks' housing quality during the 1960s. However, it is economically small, found only among renters, and certainly falls far short of the hopes and expectations of the National Committee Against Discrimination in Housing and the groups that it represented.

\section{Suburbanization, Segregation, and Neighborhood Racial Composition}

The effect of fair-housing laws on the racial composition of neighborhoods deserves special attention for at least three reasons. First, one could argue that facilitating residential integration per se was a central goal of the fair-housing legislation, distinct from the goal of improving the physical quality of blacks' housing. Second, one could argue that white neighborhoods, on average, had relatively high levels of unobserved quality (better public services, better schools, higher-human capital neighbors, etc.), and therefore, the racial integration of previously white neighborhoods could signal improved access to high-quality neighborhoods. Third, while the model outlined in section 3 suggests that the effect of the legislation on the value of black-owned housing is difficult to interpret, the effect on the value of housing in predominantly black neighborhoods is more clear: ceteris paribus, demand for housing in predominantly black neighborhoods should have fallen if fair-housing legislation effectively lowered the cost of housing elsewhere.

The IPUMS data are not particularly well-suited for analyzing changes in the degree or nature of residential segregation. The 1960 IPUMS data do not reveal city codes, and even the suburban 
location variable is compromised by confidentiality restrictions in both 1960 and $1970 .{ }^{20}$ In table 6, the IPUMS data are taken at face value, households with indeterminate suburban status are omitted, and DDD coefficients for suburban residence (conditional on residing in a metropolitan area) are estimated with the reduced samples. ${ }^{21}$ The results are sensitive to the sample restrictions that are used. With group A, the results are generally statistically weak, suggesting little or no effect of fair-housing laws on the likelihood of suburban residence, but among high school graduates who owned their homes, blacks seem to have become even less likely than whites to reside in the suburbs. Black renters in strong fairhousing states, on the other hand, seem to have slightly increased their relative likelihood of residing in the suburbs. With group B, again the results are usually statistically weak, particularly among owners, with a notable exception for the sample of recent movers in which the DDD coefficient is significant and negative. Among renters, however, the results are more consistently positive and large. When a blackonly sample is used to estimate DD coefficients, it is evident that blacks in the experimental states did not increase their likelihood of living in the suburbs relative to blacks living elsewhere, rather differences in white suburbanization across the state groups appears to drive the positive coefficients. ${ }^{22}$

Census tract-level data for metropolitan areas are especially useful for their insight into issues related to residential segregation. ${ }^{23}$ In general, census tracts are bounded by highways, rivers, railways, major streets, or other "natural" divisions, though they are subject to change as new tracts are added, old tracts are subdivided, and boundaries shift. In 1960 and 1970 in the states included in the comparison groups discussed above, approximately 4,300 people resided in the average census tract.

${ }^{20}$ In 1960 and 1970, many households have their metro status variable classified as either "not available" or "in metro area, central-city status unknown". In both cases, suburban residence is undetectable. See Ruggles and Sobek (1997) for details regarding the coverage and classification of the IPUMS “metro" variable.

${ }^{21}$ Due to the metro variable's coverage, Colorado is completely dropped from the sample in 1960 , but in the sample in 1970. Omitting Colorado in 1970 has a slight impact on the estimates.

${ }^{22}$ For owners, using group $A, \beta=0.006$ (s.e. $=0.018$ ); using group $B, \beta=-0.048$ (s.e. $=0.03$ ). For renters, using group $A, \beta=0.004$ (s.e. $=0.009$ ); using group $B, \beta=0.001$ (s.e. $=0.015$ ).

${ }^{23}$ Data are from ICPSR Studies 7552 (census tract data for 1960), 8126 (fourth count housing summary tape for 1970), and 9014 (fourth count population summary tape for 1970). The 1960 population count and housing characteristics were compiled and reported for the full population, whereas the 1970 data are based on a 20 percent sample. Education data in 1960 are based on a 25 percent sample. 
Essentially, a census tract is the closest census analogue to a neighborhood.

Unlike the IPUMS household data, the tract data identify metropolitan areas in both 1960 and 1970, and so in principle, comparisons over time within cities are possible. In practice, however, combining the census tract information for 1960 and 1970 is difficult for three reasons. First, the underlying 1970 dataset includes more suburban tracts than the 1960 dataset. By using maps and consistency tables that are included in the published census volumes for each metropolitan area in each year, one can (usually) identify the "new" areas added in 1970 and therefore make more consistent comparisons over time. With approximately 90 metropolitan areas and more than 15,000 tracts in the three sets of comparison states, this undertaking is non-trivial but feasible, and the samples used here reflect those adjustments. Second, the tract numbering scheme changed between 1960 and 1970. This makes matching the same tract over time more difficult than it need be, but not an impossible task. Third, and less remediable, there are many tract boundary changes, and this does make it impossible to fully link tracts over time. ${ }^{24}$

Here, I use a sample of census tracts from 1960 and 1970 drawn from a fixed set of metropolitan areas with adjustments made to the 1970 collection of tracts to maintain roughly the same geographic coverage within metro areas. I then calculated dissimilarity indices for each metropolitan area in each year. ${ }^{25}$ The indices are similar to those reported by Cutler, Glaeser, and Vigdor (1999), with a few differences: first, I exclude tracts covering "new" space in 1970; second, I calculate the dissimilarity index on a white vs. nonwhite basis whereas Cutler et al. work with black vs. nonblack figures (some tract-level variables used below are available only on the white vs. nonwhite basis even though basic population counts of blacks are provided); third, if a metropolitan area sits in more than

${ }^{24}$ For some cities, after one re-aggregates tracts that have been split between 1960 and 1970, the loss of coverage from boundary changes is less significant than for others. However, after having tried to make the links within several cities, it is clear that this approach is best suited for case studies as it requires tremendous attention to detail in analyzing the maps.

${ }^{25}$ The dissimilarity index is based on the distribution of people across census tracts within a metropolitan area. The measure lies between zero and one, and higher values correspond to higher levels of segregation. More precisely, dissimilarity $=1 / 2 \times \sum \mid\left(\right.$ nonwhite $_{\mathrm{i}} /$ nonwhite $\left._{\mathrm{t}}\right)-\left(\right.$ white $_{\mathrm{i}} /$ white $\left._{\mathrm{t}}\right) \mid$, where nonwhite $_{i}$ is the number of nonwhites in a particular census tracts, nonwhite is $_{\text {is }}$ the number of nonwhites in the metro area, and the summation is taken over all tracts in the area. 
one state, Cutler et al. treat it as a single unit, which is appropriate for their analysis. Given this paper's focus on state laws, if part of the metropolitan area is in a state that is not included in the study, then those tracts are omitted. ${ }^{26}$

A simple comparison of the change in the level of segregation across experimental and nonexperimental state-groups during the 1960s suggests that segregation did fall by slightly more in the experimental states than in the non-experimental states, though the differences are small. In metro areas with at least 1,000 nonwhites in 1960, the experimental state metro area segregation level fell by 0.019 , non-experimental group A fell by 0.008 , and non-experimental group B fell by $0.012 .{ }^{27}$ Looking over longer periods, Cutler et al. (1999) suggest that changes in metro area segregation levels were influenced by differences in nonwhite and white population growth rates. With that in mind, table 7 regresses the change in the segregation level between 1960 and 1970 on log nonwhite population growth, log white population growth, and the fair housing dummy variable for a sample including metro areas with at least 1,000 nonwhite residents in 1960. Observations are weighted by 1960 total population. Again, the fair-housing coefficients are economically small and statistically insignificant.

Cutler et al. (1999, table 4) show that between 1940 and 1960 there was a slight decline in the proportion of census tracts that were nearly exclusively white (at least 99 percent white), but that after 1960, there was a large decline. To the extent that residential integration was improving after 1960, it appears to have been driven largely by this decline in exclusively white neighborhoods. The "very white" row of panel A of table 8 examines census tract data from 1960 and 1970 to see whether statelevel anti-discrimination laws facilitated such integration, even if the laws made no discernable impact on the overall metro area segregation indices. The "mostly nonwhite" row focuses on the other end of the racial composition distribution, examining changes in the proportion of tracts that were mostly nonwhite (more than 50 percent). ${ }^{28}$ Appendix table A3 reports summary statistics for the census tract data.

${ }^{26}$ St. Louis (MO and IL) and Weirton-Steubenville (WV and OH) are treated as single units in the dissimilarity indices, and in table 7, they are included in both non-experimental groups. The fundamental results do not depend on their inclusion or exclusion.

${ }^{27}$ In these figures, metro area segregation levels are weighted by population.

${ }^{28}$ Counts of the black population in 1970 are suppressed if there were under 25 in a particular tract, but the nonwhite counts can be calculated as the difference between the total population and white 
Specifically, panel A reports results from OLS difference-in-difference regressions that include metropolitan-area fixed effects and control for the proportion of the area's population that is nonwhite in each year. The basic regression specification is:

$$
\mathrm{Y}_{\mathrm{ijt}}=\alpha+\gamma_{\mathrm{j}}+\beta_{1}\left(\text { Nonwhite/Pop }_{\mathrm{jt}}+\beta_{2} \text { Year }_{\mathrm{t}}+\beta_{3}\left(\mathrm{FH}_{\mathrm{j}} \times \mathrm{Year}_{\mathrm{t}}\right)\right.
$$

where $Y$ equals 1 if the census tract is "very white" and zero otherwise (in column 1), or $Y$ equals 1 if "mostly nonwhite" and zero otherwise (in column 2); $\gamma_{j}$ is a set of metropolitan area fixed effects; Nonwhite $_{j t}$ is the proportion of the metro area's population that is nonwhite in year $\mathrm{t}$; Year equals 1 in 1970 and zero in 1960; and $F H_{j} \times Y_{e a r}$ interacts fair-housing status and the year dummy. The fairhousing dummy is not entered separately because it is not identified when there are city-specific fixed effects. The coefficient on the interaction term is of particular interest because it measures the difference in the change in the probability of a census tract being "very white" (or "mostly nonwhite") between fair-housing states and non-fair-housing states, after controlling for the size of each city's nonwhite population, for a baseline trend from 1960 to 1970, and for time-invariant city-specific factors.

Between 1960 and 1970, the proportion of "very white" tracts fell from about 59 to 45 percent of the tracts in the sample. Controlling for the nonwhite proportion of each metro area's population (as described in equation 2), the decline was slightly larger in the experimental states than in nonexperimental group A, though the difference is not strongly significant; the estimate using nonexperimental group B is indistinguishable from zero. The overall proportion of "mostly nonwhite" tracts increased slightly during the 1960 s, from 8 to 12 percent of total tracts. Again, there is weakly significant evidence that this increase was smaller in the experimental states than in non-experimental group A, but there is no evidence that the change in the experimental states was different from that in non-experimental state group B.

For another perspective on neighborhood change in light of the fair-housing laws, I have designated census tracts as "high human capital tracts" if their proportion of adults (over age 24) with at least twelve years of education was above the sample median in the appropriate year (0.39 in 1960 and

population counts (which are rarely missing values). 
0.51 in 1970). Then, using a sample of those high human capital tracts in panel B of table 8 , I regress the proportion of each tract's population that was nonwhite on metropolitan-area fixed effects, the proportion of the metro area's population that was nonwhite, the proportion of the metropolitan area's stock of high school graduates that was nonwhite, a dummy variable for 1970, and the interaction of the 1970 dummy and the state fair-housing status variable. The basic idea is to see whether high human capital tracts in fair-housing states increased their proportion of nonwhite residents relative to those in non-fair housing states, ceteris paribus. While the proportion of nonwhite residents in relatively high human capital tracts increased between 1960 and 1970 (from 3.0 to about 4.6 percent), it did not increase by any more in the strong fair-housing states than in the comparison groups of states.

Finally, in panels C and D, I examine changes in the price of homes or level of rent in "mostly nonwhite" neighborhoods compared to others in a DDD framework. The regression is a slightly modified version of the earlier DDD equation, including metro area fixed effects $\left(\gamma_{j}\right)$ rather a fairhousing state dummy variable $(\mathrm{FH})$ in the first level of controls:

$$
\operatorname{lnValue}_{\mathrm{ijt}}=\alpha+\gamma_{\mathrm{j}}+\beta_{1} \operatorname{lnPop}_{\mathrm{jt}}+\beta_{2} \text { MostNW }_{\mathrm{ijt}}+\beta_{3} \text { Year }_{\mathrm{t}}+
$$

$\beta_{4}\left(\operatorname{MostNW}_{\mathrm{ijt}} \times \mathrm{FH}_{\mathrm{j}}\right)+\beta_{5}\left(\operatorname{MostNW}_{\mathrm{ijt}} \times\right.$ Year $\left._{\mathrm{t}}\right)+\beta_{6}\left(\mathrm{FH}_{\mathrm{j}} \times\right.$ Year $\left._{\mathrm{t}}\right)+\beta_{7}\left(\operatorname{MostNW}_{\mathrm{ijt}} \times \mathrm{FH}_{\mathrm{j}} \times\right.$ Year $\left._{\mathrm{t}}\right)$, where $i$ indexes tracts, $j$ indexes metropolitan areas, and $t$ indexes census years. Most $N W$ equals 1 if more than half the tract's residents are nonwhite. To capture city-specific housing demand shocks during the 1960s, I include the natural log of metro area population in the regressions, though the basic results are not sensitive to its inclusion. $\beta_{7}$ estimates the change in housing values in mostly nonwhite tracts relative to mostly white tracts in strong fair-housing states relative to weak fair-housing states. The model of section 3 suggested that the demand for and price of housing in predominantly nonwhite neighborhoods should have fallen if the conventional description of high demand and prices for housing in nonwhite neighborhoods is accurate and if the fair-housing laws worked as intended. Again, there is no evidence for a significant fair-housing impact in panels $\mathrm{C}$ and $\mathrm{D}$.

If the tracts that became mostly nonwhite between 1960 and 1970 had higher than average housing quality than those originally counted as mostly nonwhite, then the comparisons over time of 
property values in "nonwhite neighborhoods" could be biased upward. ${ }^{29}$ The extent of this bias would have to differ across the state groups to influence the DDD estimates in panels C and D. But to make sure that "new" mostly nonwhite tracts are not confounding the results in panels C and D, it helps to compare the geographic coverage of the 1960 and 1970 mostly nonwhite tracts using the maps in each metropolitan area's census volume, and then to identify tracts that were mostly nonwhite in both census years. ${ }^{30}$ After doing so, I re-ran the regressions, assigning tracts "mostly nonwhite" status only if they were clearly mostly nonwhite in both 1960 and 1970 - the idea is to compare (roughly) constant areas of coverage for nonwhite and white tracts over time. The results are substantively unchanged: there is no evidence of a relative decline in housing prices in nonwhite neighborhoods due to the fair-housing laws.

\section{Conclusions}

In examining both federal and state-level laws, the economics literature on the labor market impact of anti-discrimination policies is much deeper than the literature on the housing market impact of anti-discrimination policies. While audit studies suggest that housing market discrimination is still common and costly (Yinger 1998), much less is known about the extent to which legislation has reduced discrimination's effect on housing market outcomes over time. This is somewhat surprising given fair-housing's prominent place among the Civil Rights Movement's legislative accomplishments and given the central role that housing discrimination has played in the evolution of urban economies and the development of urban policy.

States passed fair housing laws at different times, providing useful variation for the measurement of the policy's impact on housing market outcomes of blacks relative to whites. This paper's analysis of home ownership rates, housing values, residential segregation, and housing characteristics indicates that the state-level fair-housing laws did not have a strong positive influence on the housing market

\footnotetext{
29 In the 1970 data, it does appear that the "new" mostly nonwhite areas had higher property
} values and rents than the original mostly nonwhite areas.

${ }^{30}$ Because exactly matching the tracts is impossible due to boundary changes, this exercise is quite imperfect, but it goes a considerable distance to improving the comparisons over time. 
outcomes of African Americans. Even among relatively young household heads, relatively welleducated household heads, and household heads who had recently moved, the overriding message from the data is that the state-laws did not have an economically significant positive effect during the 1960s. There is some evidence, from the hedonic indices, that renters in strong fair-housing states slightly improved their housing quality relative to those elsewhere, but the estimates are economically small ( 2 to 4 percent). There is also some evidence from the IPUMS data in table 6 that the racial gap in suburban residence rates declined more in fair housing states than elsewhere, but this did not lead to larger declines in metro area residential segregation (table 7) or to larger increases in blacks' residence in high human capital neighborhoods (table 8).

Importantly, African Americans' average housing market outcomes did improve relative to those of whites during the 1960s, even after controlling for income and educational gains. Moreover, in the sample of northeastern and midwestern states analyzed here, the proportion of exclusively white neighborhoods declined markedly, and African-American households increased their representation in neighborhoods with relatively high levels of human capital. It appears, however, that state fair-housing laws did not make a large contribution to that progress.

The usual concerns about the endogeneity of laws and about unobserved events that differentially affected blacks relative to whites in strong fair-housing states relative to non-experimental states arise here as well. Although policymakers and fair-housing advocates were obviously concerned with blacks' housing market outcomes, studies of the political history of state fair-housing legislation do not suggest that differences in the timing of adoption across states were driven by differential changes in blacks' relative housing market outcomes. The changing size of the black population would be a prime candidate for linking policy changes and changes in average black housing market outcomes, but the results are generally insensitive to adding controls for the black proportion of each state's population. Dealing with potentially confounding unobserved phenomena is inherently difficult, though the DDD strategy, in combination with the long list of independent variables (income, education, etc.), is designed to control for housing market influences other than those coming from the fair-housing laws. Nonetheless, it is possible that changes in discriminatory sentiment or the twin policies of urban renewal 
and public housing had an independent influence on blacks' relative housing market outcomes. On the basis of the existing evidence, it is difficult to argue that their influence was significantly uneven across all the state groups compared here.

Could the federal Fair Housing Act of 1968 have made a more substantial contribution to African-Americans' economic progress than the non-southern state laws did? A more direct examination of the federal impact would certainly be worth undertaking, but on the basis of the evidence presented in this paper, a significant federal effect seems unlikely. First, the state laws, though weak, were generally stronger than the 1968 federal law, and they appear to have had little impact. Second, if housing market discrimination became less overt over time, then the early state laws may have had more easily identifiable targets than the later federal law. From a broader perspective, however, it has been argued that an array of federal anti-discrimination efforts made their largest labor market impact in the South (Donohue and Heckman 1991), and it is possible, though far from certain, that the federal efforts also had a concentrated regional impact on housing markets. It is also possible that the federal fair-housing legislation, passed almost immediately after the assassination of Martin Luther King, Jr. and the ensuing riots, somehow influenced public opinion in a way that diminished discriminatory norms. But again, the existence of such an effect is by no means certain, and the hypothesis awaits direct, econometric examination. 


\section{$\underline{\text { References }}$}

Abrams, Charles. Forbidden Neighbors: A Study of Prejudice in Housing. New York: Harper \& Brothers, 1955.

Becker, Gary S. The Economics of Discrimination. Chicago: University of Chicago Press, 1957.

Bergman, Barbara and Jerolyn Lyle. "The Occupational Standing of Negroes by Areas and Industries." Journal of Human Resources 6 (1971): 411-433.

Besley, Timothy and Anne Case. "Unnatural Experiments? Estimating the Incidence of Endogenous Policies.” Economic Journal 110, 467 (2000): F672-94.

Bianchi, Suzanne M., Farley Reynolds, and Daphne Spain. "Racial Inequalities in Housing: An Examination of Recent Trends." Demography 19, 1 (1982): 37-51.

Brooks, Richard R. W. "Covenants and Conventions: An Analysis of Racial Restrictive Covenants." Northwestern University Law School, working paper, 2002.

Casstevens, Thomas W. "California's Rumford Act and Proposition 14." In The Politics of FairHousing Legislation: State and Local Case Studies, edited by Lynn W. Eley and Thomas W. Casstevens. San Francisco, CA: Chandler Publishing Company, 1968: 237-284.

Collins, William J. "The Labor Market Impact of State-Level Anti-Discrimination Laws, 1940-1960." Industrial and Labor Relations Review 56 (2003): 244-272.

Collins, William J. “The Political Economy of Fair Housing Laws, 1950-1968.” Working paper, 2002.

Collins, William J. and Robert A. Margo. "When Did Ghettos Go Bad? Residential Segregation and Socioeconomic Outcomes." Economics Letters 69 (2000): 239-243.

Collins, William J. and Robert A. Margo. "Race and Home Ownership: A Century-Long View." Explorations in Economic History 38 (2001): 68-92.

Collins, William J. and Robert A. Margo. "Race and the Value of Owner Occupied Housing, 19401990." Regional Science and Urban Economics, forthcoming 2003.

Courant, Paul N. "Racial Prejudice in a Search Model of the Urban Housing Market." Journal of Urban Economics 5 (1978): 329-345.

Courant, Paul N. and John Yinger. "On Models of Racial Prejudice and Urban Residential Structure.” Journal of Urban Economics 4 (1977) 272-291. 
Cutler, David M. and Glaeser, Edward L. “Are Ghettos Good or Bad?” Quarterly Journal of Economics 112 (1997): 827-872.

Cutler, David M., Glaeser, Edward L., and Vigdor, Jacob L. "The Rise and Decline of the American Ghetto,” Journal of Political Economy 107 (1999): 455-506.

Donohue, John J. III and James Heckman. "Continuous Versus Episodic Change: The Impact of Civil Rights Policy on the Economic Status of Blacks." Journal of Economic Literature 29 (1991): 1603-1643.

Greeley, Andrew M. and Paul B. Sheatsley. "Attitudes toward Racial Integration." Scientific American 225, 6 (December 1971).

Heckman, James J. "Simultaneous Equation Models with Continuous and Discrete Endogenous Variables and Structural Shifts." In Studies in Non-Linear Estimation, edited by Stephen M. Goldfeld and Richard E. Quandt. Cambridge, MA: Ballinger, 1976: 235-72.

Housing and Home Finance Agency. Fair Housing Laws: Summaries and Text of State and Municipal Laws. Washington, D.C.: GPO 1964.

Kain, John F. “Housing Segregation, Negro Employment, and Metropolitan Decentralization.” Quarterly Journal of Economics 82, 2 (May 1968): 175-197.

Kain, John F. and John M. Quigley. Housing Markets and Racial Discrimination: A Microeconomic Analysis. New York: Columbia University Press, 1975.

King, Thomas and Peter Mieszkowski. "Racial Discrimination, Segregation, and the Price of Housing." Journal of Political Economy 81, 3 (1973): 590-606.

Landes, William M. “The Economics of Fair Employment Laws.” Journal of Political Economy 76, 4 (1968): 507-52.

Landye, Thomas M. and James J. Vanecko. "The Politics of Open Housing in Chicago and Illinois." In The Politics of Fair-Housing Legislation: State and Local Case Studies, edited by Lynn W. Eley and Thomas W. Casstevens. San Francisco, CA: Chandler Publishing Company, 1968: 65-104.

Lockard, Duane. Toward Equal Opportunity: A Study of State and Local Antidiscrimination Laws. New York: Macmillan Company, 1968.

Massey, Douglas S. and Nancy A. Denton. American Apartheid: Segregation and the Making of the Underclass. Cambridge, MA: Harvard University Press, 1993. 
Meyer, Bruce D. "Natural and Quasi-Experiments in Economics." Journal of Business and Economic Statistics 13, 2 (1995): 151-62.

Meyer, Stephen Grant. As Long As They Don't Move Next Door: Segregation and Racial Conflict in American Neighborhoods. New York: Rowman \& Littlefield, 2000.

Myrdal, Gunnar. An American Dilemma: The Negro Problem and Modern Democracy. New York: Harper \& Row, 1962 (originally 1944).

National Committee Against Discrimination in Housing. Trends in Housing. Various issues.

Neumark, David and Wendy A. Stock. "The Effects of Race and Sex Discrimination Laws.” National Bureau of Economic Research Working Paper 8215. Cambridge, MA: 2001.

Oliver, M.L. and T.M. Shapiro. Black Wealth/White Wealth: A New Perspective on Racial Inequality. New York: Routledge, 1995.

Osofsky, Gilbert. Harlem: The Making of a Ghetto. New York: Harper \& Row, 1966.

Ruggles, Steven, Matthew Sobek, et al. Integrated Public Use Microdata Series. Minneapolis: Historical Census Projects, University of Minnesota, 1997.

Schuman, Howard, Charlotte Steeh, Lawrence Bobo, and Maria Krysan. Racial Attitudes in America: Trends and Interpretations. Cambridge: Harvard University Press, 1997.

Staples, John H. "Urban Renewal: A Comparative Study of Twenty-Two Cities, 1950-1960." Western Political Quarterly 23, 2 (1970): 294-304.

Stigler, George. "The Sources of Economic Legislation - 1: Fair Employment Legislation." Unpublished paper, University of Chicago, 1973.

Sugrue, Thomas J. The Origins of the Urban Crisis: Race and Inequality in Postwar Detroit. Princeton, NJ: Princeton University Press, 1996.

U.S. Commission on Civil Rights. Understanding Fair Housing. Washington, D.C.: Government Printing Office, 1973.

U.S. Department of Housing and Urban Development. 1970 HUD Statistical Yearbook. Washington, D.C.: GPO, 1971.

Weaver, Robert C. The Negro Ghetto. New York: Russell \& Russell, 1967 (originally 1948).

Weicher, John C. Urban Renewal: National Program for Local Problems. Washington, D.C.: American Enterprise Institute, 1972. 
White, Michael J. Urban Renewal and the Changing Residential Structure of the City. Chicago: The Community and Family Study Center, University of Chicago, 1980.

Wilson, William J. The Truly Disadvantaged: The Inner City, the Underclass, and Public Policy. Chicago: University of Chicago Press, 1987.

Yinger, John. "Housing Discrimination and Residential Segregation as Causes of Poverty." In Understanding Poverty, edited by Sheldon H. Danziger and Robert H. Haveman. Cambridge, MA: Harvard University Press, 2001: 359-391.

Yinger, John. "Sustaining the Fair Housing Act." Cityscape: A Journal of Policy Development and Research 4, 3 (1999): 93-105.

Yinger, John. "Evidence on Discrimination in Consumer Markets." Journal of Economic Perspectives 12, 2 (1998): 23-40. 
Table 1: State Fair Housing Laws

\begin{tabular}{|c|c|c|c|}
\hline & $\begin{array}{l}\text { Not Including Owner- } \\
\text { Occupied Housing }\end{array}$ & $\begin{array}{l}\text { Not Including Owner- } \\
\text { Occupied Housing, } \\
\text { But Including All Real } \\
\text { Estate Broker Activities }\end{array}$ & $\begin{array}{l}\text { Including Owner- } \\
\text { Occupied Housing }\end{array}$ \\
\hline Alaska & & & 1962 \\
\hline California & & 1963 & \\
\hline Colorado & 1959 & & 1965 \\
\hline Connecticut & 1959 & & 1963 \\
\hline Hawaii & & & 1967 \\
\hline Indiana & & & 1965 \\
\hline Iowa & & & 1967 \\
\hline Kentucky & & 1968 & \\
\hline Maine & 1965 (rental only) & & \\
\hline Maryland & 1967 (new only) & & \\
\hline Massachusetts & 1959 & & 1963 \\
\hline Michigan & & & 1964 \\
\hline Minnesota & 1962 & & 1967 \\
\hline New Hampshire & 1961 (rental only) & & 1965 \\
\hline New Jersey & 1961 & & 1966 \\
\hline New York & 1961 & & 1963 \\
\hline Ohio & 1965 & & \\
\hline Oregon & & 1959 & \\
\hline Pennsylvania & 1961 & & \\
\hline Rhode Island & & & 1965 \\
\hline Vermont & & & 1967 \\
\hline Washington & $\begin{array}{l}1967 \text { (pending } \\
\text { referendum) }\end{array}$ & & \\
\hline Wisconsin & 1965 & & \\
\hline
\end{tabular}

Note: California's law was suspended in 1964 by a constitutional amendment; it was reinstated in 1966 when the state supreme court ruled that the amendment was unconstitutional (Casstevens 1968). Sources: The table draws heavily on Trends in Housing (a bi-monthly publication of the National Committee Against Discrimination in Housing) and on Fair Housing Laws: Summaries and Text of State and Municipal Laws (published by the Housing and Home Finance Agency in 1964). Case studies in Eley and Casstevens (1968) have also been helpful. 
Table 2: Characteristics of Experimental and Non-Experimental State-Group Samples

\begin{tabular}{lccc}
\hline & $\begin{array}{c}\text { Experimental } \\
\text { States }\end{array}$ & $\begin{array}{c}\text { Non- } \\
\text { Experimental } \\
\text { States, } \\
\text { Group A }\end{array}$ & $\begin{array}{c}\text { Non- } \\
\text { Experimental } \\
\text { States, } \\
\text { Group B }\end{array}$ \\
\hline 1960 characteristics & & & \\
$\quad$ Nonwhite proportion of population & 0.07 & 0.08 & 0.10 \\
Ownership rate & 0.58 & 0.63 & 0.63 \\
Ownership rate (B-W) & -0.34 & -0.34 & -0.27 \\
Persons per room (all) & 0.75 & 0.74 & 0.78 \\
Persons per room (B-W) & 0.17 & 0.18 & 0.20 \\
Proportion of households in old stock & 0.49 & 0.52 & 0.41 \\
Proportion of households in old stock (B-W) & 0.23 & 0.27 & 0.29 \\
Proportion of households w/ two baths & 0.08 & 0.07 & 0.09 \\
Proportion of households w/ two baths (B-W) & -0.05 & -0.04 & -0.06 \\
Average log family income (all) & 8.69 & 8.65 & 8.54 \\
Average log family income (B-W) & -0.54 & -0.53 & -0.59 \\
Votes for George Wallace (1968) & 0.07 & 0.09 & 0.12 \\
& & & \\
1950-1960 trends & & & \\
Change in nonwhite proportion of population & 0.019 & 0.019 & 0.011 \\
Change in prop. of owner-occ. units (all) & 0.072 & 0.076 & 0.067 \\
Change in prop. of owner-occ. units (NW-W) & -0.037 & -0.038 & -0.021 \\
Prop. of 1960 housing units built since 1950 & 0.23 & 0.22 & 0.25 \\
Change in log family income (all) & 0.59 & 0.59 & 0.63 \\
Change in log family income (B-W) & -0.12 & -0.0043 & -0.096 \\
\hline
\end{tabular}

Notes: Nonwhite proportion of the population, change in proportion of owner-occupied units, and proportion of units built during the 1950s are calculated using the published population and housing census volumes. Other variables are calculated using the IPUMS samples in 1960 and 1950 . The samples drawn from the IPUMS include black and white native-born household heads, age 20 to 59, who were not in school nor in the armed services, who had positive income, and who were not missing information regarding migrant status. Non-experimental group A includes: Illinois, Ohio, Pennsylvania, and Wisconsin. Non-experimental group B includes: Delaware, Maryland, Kansas, Missouri, and West Virginia. The experimental states include: Connecticut, Colorado, Indiana, Massachusetts, Michigan, New York, and Rhode Island.

Sources: Household-level data were taken from the IPUMS (Ruggles and Sobek 1997). As noted, state-level data were taken from various volumes of the published population and housing censuses in 1950 and 1960. Votes for George Wallace are from http://www.uselectionatlas.org/. 
Table 3: Home Ownership, Household Size, and Fair Housing Laws, DDD Estimates, 1960-1970

\begin{tabular}{|c|c|c|}
\hline Non-Experimental Group & With Group A & With Group B \\
\hline \multicolumn{3}{|l|}{ Ownership (probit) } \\
\hline All households & $\begin{array}{c}-0.0154 \\
(1.09) \\
{[289058]}\end{array}$ & $\begin{array}{c}0.0248 \\
(1.30) \\
{[196732]}\end{array}$ \\
\hline All, w/ state and state-year dummies & $\begin{array}{c}-0.00661 \\
(0.46)\end{array}$ & $\begin{array}{c}0.0169 \\
(0.87)\end{array}$ \\
\hline All, w/ prop. blk and blk $\times$ prop. blk & $\begin{array}{c}0.00983 \\
(0.69)\end{array}$ & $\begin{array}{l}0.0407 \\
(2.13)\end{array}$ \\
\hline Head $<40$ years of age & $\begin{array}{c}-0.0215 \\
(0.92) \\
{[128512]}\end{array}$ & $\begin{array}{c}0.0103 \\
(0.32) \\
{[87695]}\end{array}$ \\
\hline Head $>11$ years of education & $\begin{array}{c}-0.00546 \\
(0.23) \\
{[161433]}\end{array}$ & $\begin{array}{c}0.0452 \\
(1.35) \\
{[110494]}\end{array}$ \\
\hline Movers & $\begin{array}{c}0.0109 \\
(0.51) \\
{[143794]} \\
\end{array}$ & $\begin{array}{c}0.0443 \\
(1.53) \\
{[99104]} \\
\end{array}$ \\
\hline \multicolumn{3}{|l|}{ Household Size (OLS) } \\
\hline All households & $\begin{array}{c}0.00182 \\
(0.03) \\
{[294875]}\end{array}$ & $\begin{array}{c}0.0151 \\
(0.18) \\
{[200859]}\end{array}$ \\
\hline All, w/ state and state-year dummies & $\begin{array}{c}0.00475 \\
(0.08)\end{array}$ & $\begin{array}{c}0.0167 \\
(0.20)\end{array}$ \\
\hline All, w/ prop. blk and blk $\times$ prop. blk & $\begin{array}{c}0.0147 \\
(0.26)\end{array}$ & $\begin{array}{c}0.0195 \\
(0.23)\end{array}$ \\
\hline Head $<40$ years of age & $\begin{array}{c}0.0504 \\
(0.65) \\
{[131407]}\end{array}$ & $\begin{array}{c}0.278 \\
(2.35) \\
{[112305]}\end{array}$ \\
\hline Head > 11 years of education & $\begin{array}{c}0.0620 \\
(0.71) \\
{[163885]}\end{array}$ & $\begin{array}{c}-0.0982 \\
(0.78) \\
{[112305]}\end{array}$ \\
\hline Movers & $\begin{array}{c}-0.0227 \\
(0.30) \\
{[145465]}\end{array}$ & $\begin{array}{c}0.132 \\
(1.17) \\
{[100318]}\end{array}$ \\
\hline
\end{tabular}

Notes: The dependent variable for the ownership regressions equals 1 if unit is owner-occupied and 0 otherwise. The dependent variable for the household size regressions is the number of "person records" in the sampled household. t-stats (OLS) or z-stats (probit) based on robust standard errors are in parentheses. Each reported coefficient is from a separate regression and relates to the interaction of the fair housing, black, and 1970 indicator variables. The ownership probit regressions control for 
the household head's age (quartic), years of education (quadratic), marital status, sex, veteran status, and migrant status (whether changed states in last five years), as well as the household's number of members (quadratic), number of children (series of indicators), and log family income (adjusted to 1969 dollars; plus a dummy for top-coded income). The coefficient is expressed in $\mathrm{dF} / \mathrm{dX}$ form. The household size regressions do not include household characteristics. Ownership regression samples include native-born household heads from age 20 to 59, with positive income, who did not live on a farm, who were not in the military, and who were not missing information on the control variables. Household size regressions include all native-born non-farm household heads from age 20 to 59. "Movers" are household heads living in a residence that is different from the one they lived in five years earlier. Non-experimental group A includes: Illinois, Ohio, Pennsylvania, and Wisconsin. Nonexperimental group B includes: Delaware, Maryland, Kansas, Missouri, and West Virginia. The experimental states include: Connecticut, Colorado, Indiana, Massachusetts, Michigan, New York, and Rhode Island.

Sources: Micro-level census data are from the IPUMS for 1960 and 1970 (Ruggles and Sobek 1997). 
Table 4: Housing Characteristics and Fair Housing Laws, DDD Estimates, 1960-1970

\begin{tabular}{|c|c|c|c|c|c|c|}
\hline \multirow{2}{*}{$\begin{array}{l}\text { Variable } \\
\text { Non-Experimental Group }\end{array}$} & \multicolumn{2}{|c|}{ Two Baths (Probit) } & \multicolumn{2}{|c|}{ Old Building (Probit) } & \multicolumn{2}{|c|}{ Rooms (OLS) } \\
\hline & A & B & A & B & A & B \\
\hline \multicolumn{7}{|l|}{ Owners } \\
\hline All households & $\begin{array}{c}-0.00754 \\
(0.38) \\
{[164839]} \\
\{0.17\}\end{array}$ & $\begin{array}{c}-0.00978 \\
(0.35) \\
{[109984]} \\
\{0.18\}\end{array}$ & $\begin{array}{c}0.0159 \\
(0.67) \\
{[181457]} \\
\{0.37\}\end{array}$ & $\begin{array}{c}-0.00527 \\
(0.19) \\
{[120930]} \\
\{0.34\}\end{array}$ & $\begin{array}{c}-0.198 \\
(3.20) \\
{[181457]} \\
\{5.90\}\end{array}$ & $\begin{array}{c}-0.254 \\
(3.17) \\
{[120930]} \\
\{5.89\}\end{array}$ \\
\hline $\begin{array}{l}\text { All, w/ state and } \\
\text { state-year dummies }\end{array}$ & $\begin{array}{c}-0.00908 \\
(0.46)\end{array}$ & $\begin{array}{c}-0.0116 \\
(0.42)\end{array}$ & $\begin{array}{c}0.000485 \\
(0.02)\end{array}$ & $\begin{array}{c}-0.0189 \\
(0.67)\end{array}$ & $\begin{array}{c}-0.224 \\
(3.66)\end{array}$ & $\begin{array}{r}-0.249 \\
(3.12)\end{array}$ \\
\hline $\begin{array}{c}\text { All, w/ prop. blk and } \\
\text { blk } \times \text { prop.blk }\end{array}$ & $\begin{array}{c}-0.00723 \\
(0.36)\end{array}$ & $\begin{array}{c}-0.0134 \\
(0.47)\end{array}$ & $\begin{array}{c}0.0265 \\
(1.11)\end{array}$ & $\begin{array}{c}-0.00538 \\
(0.19)\end{array}$ & $\begin{array}{l}-0.158 \\
(2.53)\end{array}$ & $\begin{array}{l}-0.257 \\
(3.21)\end{array}$ \\
\hline Head $<40$ yrs age & $\begin{array}{c}-0.0180 \\
(0.63) \\
{[61690]}\end{array}$ & $\begin{array}{c}-0.011 \\
(0.27) \\
{[41416]}\end{array}$ & $\begin{array}{c}0.0460 \\
(1.29) \\
{[68284]}\end{array}$ & $\begin{array}{c}0.0251 \\
(0.59) \\
{[45731]}\end{array}$ & $\begin{array}{c}-0.137 \\
(1.37) \\
{[68284]}\end{array}$ & $\begin{array}{c}-0.113 \\
(0.83) \\
{[45731]}\end{array}$ \\
\hline Head >11 yrs education & $\begin{array}{c}0.034 \\
(0.79) \\
{[97409]}\end{array}$ & $\begin{array}{c}0.0143 \\
(0.24) \\
{[65509]}\end{array}$ & $\begin{array}{c}0.0298 \\
(0.081) \\
{[105969]}\end{array}$ & $\begin{array}{c}0.0257 \\
(0.56) \\
{[71232]}\end{array}$ & $\begin{array}{c}-0.185 \\
(1.73) \\
{[105969]}\end{array}$ & $\begin{array}{c}-0.196 \\
(1.38) \\
{[71232]}\end{array}$ \\
\hline Movers (in last 5 yrs) & $\begin{array}{c}0.023 \\
(0.038) \\
{[63585]}\end{array}$ & $\begin{array}{c}0.00898 \\
(0.18) \\
{[43646]}\end{array}$ & $\begin{array}{c}0.0279 \\
(0.88) \\
{[70574]}\end{array}$ & $\begin{array}{c}-0.0302 \\
(0.82) \\
{[48300]}\end{array}$ & $\begin{array}{c}-0.180 \\
(1.89) \\
{[70574]}\end{array}$ & $\begin{array}{c}-0.160 \\
(0.27) \\
{[48300]}\end{array}$ \\
\hline \multicolumn{7}{|l|}{ Renters } \\
\hline All households & $\begin{array}{c}0.00221 \\
(0.37) \\
{[97217]} \\
\{0.032\}\end{array}$ & $\begin{array}{c}0.00453 \\
(0.55) \\
{[68585]} \\
\{0.035\}\end{array}$ & $\begin{array}{c}0.00738 \\
(0.44) \\
{[107601]} \\
\{0.64\}\end{array}$ & $\begin{array}{c}0.00193 \\
(0.08) \\
{[75802]} \\
\{0.61\}\end{array}$ & $\begin{array}{c}-0.254 \\
(6.04) \\
{[107601]} \\
\{4.28\}\end{array}$ & $\begin{array}{c}-0.192 \\
(3.14) \\
{[75802]} \\
\{4.23\}\end{array}$ \\
\hline $\begin{array}{l}\text { All, w/ state and } \\
\text { state-year dummies }\end{array}$ & $\begin{array}{c}0.00337 \\
(0.56)\end{array}$ & $\begin{array}{c}0.00823 \\
(0.95)\end{array}$ & $\begin{array}{l}-0.017 \\
(0.99)\end{array}$ & $\begin{array}{c}-0.0498 \\
(1.97)\end{array}$ & $\begin{array}{l}-0.234 \\
(5.59)\end{array}$ & $\begin{array}{l}-0.192 \\
(3.16)\end{array}$ \\
\hline $\begin{array}{c}\text { All, w/ prop. blk and } \\
\text { blk } \times \text { prop.blk }\end{array}$ & $\begin{array}{c}0.00358 \\
(0.59)\end{array}$ & $\begin{array}{c}0.00501 \\
(0.60)\end{array}$ & $\begin{array}{c}0.0109 \\
(0.64)\end{array}$ & $\begin{array}{c}-0.00449 \\
(0.19)\end{array}$ & $\begin{array}{l}-0.212 \\
(5.04)\end{array}$ & $\begin{array}{l}-0.206 \\
(3.37)\end{array}$ \\
\hline Head $<40$ yrs age & $\begin{array}{c}0.00677 \\
(0.85) \\
{[54721]}\end{array}$ & $\begin{array}{c}0.00228 \\
(0.24) \\
{[38241]}\end{array}$ & $\begin{array}{c}0.0545 \\
(2.43) \\
{[60228]}\end{array}$ & $\begin{array}{c}0.0855 \\
(2.67) \\
{[41964]}\end{array}$ & $\begin{array}{l}-0.207 \\
(0.054) \\
{[60228]}\end{array}$ & $\begin{array}{c}-0.104 \\
(1.34) \\
{[41964]}\end{array}$ \\
\hline Head $>11$ yrs ed. & $\begin{array}{c}0.00247 \\
(0.19) \\
{[50840]}\end{array}$ & $\begin{array}{c}-0.00477 \\
(0.27) \\
{[36006]}\end{array}$ & $\begin{array}{c}-0.0176 \\
(0.57) \\
{[55464]}\end{array}$ & $\begin{array}{c}0.0242 \\
(0.52) \\
{[39262]}\end{array}$ & $\begin{array}{c}-0.285 \\
(3.95) \\
{[55464]}\end{array}$ & $\begin{array}{c}-0.291 \\
(2.55) \\
{[39262]}\end{array}$ \\
\hline Movers (in last five yrs) & $\begin{array}{c}0.00807 \\
(1.02) \\
{[66315]}\end{array}$ & $\begin{array}{c}0.00317 \\
(0.32) \\
{[46091]}\end{array}$ & $\begin{array}{c}-0.00498 \\
(0.23) \\
{[73220]}\end{array}$ & $\begin{array}{c}0.0205 \\
(0.67) \\
{[50804]}\end{array}$ & $\begin{array}{c}-0.240 \\
(4.64) \\
{[73220]}\end{array}$ & $\begin{array}{c}-0.130 \\
(1.77) \\
{[50804]}\end{array}$ \\
\hline
\end{tabular}

Notes: t-stats (OLS) or z-stats (probit) based on robust standard errors are in parentheses. The number of observations are in square brackets. Mean values dependent variables values are in curved 
brackets. Sample sizes change when particular housing characteristics are unreported. See notes to table 3 for descriptions of state-groups. The "old building" variable equals one for buildings over 30 years old (the topcode in 1960 and 1970). Each reported coefficient is from a separate regression and relates to the interaction of the fair housing, black, and 1970 indicator variables. The regressions control for the household head's age (quartic), years of education (quadratic), marital status, sex, veteran status, and migrant status (whether changed states in last five years), as well as the household's number of members (quadratic), number of children (series of indicators), and log family income (adjusted to 1969 dollars; plus a dummy for top-coded income). The coefficients for "two baths" and "old building" are from probits and expressed in $\mathrm{dF} / \mathrm{dX}$ form evaluated at sample means. "Movers" are household heads living in a residence that is different from the one they lived in five years earlier. Sources: Micro-level census data are from the IPUMS for 1960 and 1970 (Ruggles and Sobek 1997). 
Table 5: Hedonic Valuation of Housing and Fair Housing Laws, DDD Estimates, 1960-1970

\begin{tabular}{|c|c|c|}
\hline Non-Experimental Group & With Group A & With Group B \\
\hline \multicolumn{3}{|l|}{ Owners (OLS) } \\
\hline All households & $\begin{array}{c}-0.0137 \\
(0.86) \\
{[141467]} \\
\{9.70\}\end{array}$ & $\begin{array}{c}-0.0297 \\
(1.35) \\
{[93497]} \\
\{9.69\}\end{array}$ \\
\hline All households, w/ state and state-year dummies & $\begin{array}{c}-0.0107 \\
(0.67)\end{array}$ & $\begin{array}{c}-0.0298 \\
(1.36)\end{array}$ \\
\hline All households, w/ prop. blk and blk $\times$ prop.blk & $\begin{array}{c}-0.0158 \\
(1.00)\end{array}$ & $\begin{array}{c}-0.0300 \\
(1.37)\end{array}$ \\
\hline Head $<40$ yrs age & $\begin{array}{c}-0.0437 \\
(1.65) \\
{[53307]}\end{array}$ & $\begin{array}{c}-0.0293 \\
(0.83) \\
{[35439]}\end{array}$ \\
\hline Head $>11$ yrs education & $\begin{array}{c}-0.046 \\
(1.77) \\
{[85410]}\end{array}$ & $\begin{array}{c}-0.0236 \\
(0.67) \\
{[57004]}\end{array}$ \\
\hline Movers (in last 5 yrs) & $\begin{array}{c}-0.0167 \\
(0.65) \\
{[53952]} \\
\end{array}$ & $\begin{array}{c}-0.00960 \\
(0.28) \\
{[36728]} \\
\end{array}$ \\
\hline \multicolumn{3}{|l|}{ Renters (OLS) } \\
\hline All households & $\begin{array}{c}0.0214 \\
(3.78) \\
{[92135]} \\
\{4.38\}\end{array}$ & $\begin{array}{c}0.0410 \\
(3.76) \\
{[64881]} \\
\{4.36\}\end{array}$ \\
\hline All households, w/ state and state-year dummies & $\begin{array}{c}0.0288 \\
(4.99)\end{array}$ & $\begin{array}{c}0.0479 \\
(4.36)\end{array}$ \\
\hline All households, w/ prop. blk and blk $\times$ prop. blk & $\begin{array}{c}0.0236 \\
(4.16)\end{array}$ & $\begin{array}{c}0.0374 \\
(3.51)\end{array}$ \\
\hline Head $<40$ yrs age & $\begin{array}{c}0.0251 \\
(3.39) \\
{[52157]}\end{array}$ & $\begin{array}{c}0.0312 \\
(2.24) \\
{[36364]}\end{array}$ \\
\hline Head $>11$ yrs ed. & $\begin{array}{c}0.0304 \\
(3.41) \\
{[48162]}\end{array}$ & $\begin{array}{c}0.000455 \\
(0.02) \\
{[34201]}\end{array}$ \\
\hline Movers (in last five yrs) & $\begin{array}{c}0.0205 \\
(2.89) \\
{[63490]}\end{array}$ & $\begin{array}{c}0.0434 \\
(3.35) \\
{[43927]}\end{array}$ \\
\hline
\end{tabular}

Notes: t-statistics are in parentheses. The number of observations is in square brackets. The mean value of the dependent variable is in curved brackets. See notes to table 3 for descriptions of stategroups. The text describes the construction of the hedonic indices; note that for owners, the figures 
relate to property values; for renters, the figures relate to monthly rent. The regressions control for the household head's age (quartic), years of education (quadratic), marital status, sex, veteran status, and migrant status (whether changed states in last five years), as well as the household's number of members (quadratic), number of children (series of indicators), and $\log$ family income (adjusted to 1969 dollars; plus a dummy for top-coded income). "Movers" are household heads living in a residence that is different from the one they lived in five years earlier.

Sources: Micro-level census data are from the IPUMS for 1960 and 1970 (Ruggles and Sobek 1997). 
Table 6: Suburban Residence and Fair Housing Laws, DDD Estimates, 1960-1970

\begin{tabular}{|c|c|c|}
\hline Non-Experimental Group & With Group A & With Group B \\
\hline \multicolumn{3}{|l|}{ Owners (probit) } \\
\hline All households & $\begin{array}{c}0.0296 \\
(1.13) \\
{[131968]} \\
\{0.65\}\end{array}$ & $\begin{array}{c}-0.00215 \\
(0.05) \\
{[74723]} \\
\{0.65\}\end{array}$ \\
\hline All, w/ state and state-year dummies & $\begin{array}{c}0.00173 \\
(0.06)\end{array}$ & $\begin{array}{c}-0.0402 \\
(0.83)\end{array}$ \\
\hline All, w/ prop. blk and blk $\times$ prop. blk & $\begin{array}{c}0.00424 \\
(0.16)\end{array}$ & $\begin{array}{c}-0.0345 \\
(0.77)\end{array}$ \\
\hline Head $<40$ yrs age & $\begin{array}{c}0.00661 \\
(0.16) \\
{[49145]}\end{array}$ & $\begin{array}{c}-0.0183 \\
(0.26) \\
{[28287]}\end{array}$ \\
\hline Head $>11$ yrs education & $\begin{array}{c}-0.101 \\
(2.18) \\
{[78600]}\end{array}$ & $\begin{array}{c}-0.0497 \\
(0.66) \\
{[45655]}\end{array}$ \\
\hline Movers (in last 5 yrs) & $\begin{array}{c}-0.0101 \\
(0.25) \\
{[78600]}\end{array}$ & $\begin{array}{c}-0.170 \\
(2.40) \\
{[29638]} \\
\end{array}$ \\
\hline \multicolumn{3}{|l|}{$\overline{\text { Renters (probit) }}$} \\
\hline All households & $\begin{array}{c}0.0324 \\
(1.53) \\
{[86071]} \\
\{0.31\}\end{array}$ & $\begin{array}{c}0.115 \\
(2.89) \\
{[52799]} \\
\{0.28\}\end{array}$ \\
\hline All, w/ state and state-year dummies & $\begin{array}{c}0.0407 \\
(1.84)\end{array}$ & $\begin{array}{l}0.114 \\
(2.57)\end{array}$ \\
\hline All, w/ prop. blk and blk $\times$ prop. blk & $\begin{array}{c}0.0103 \\
(0.49)\end{array}$ & $\begin{array}{c}0.0502 \\
(1.28)\end{array}$ \\
\hline Head $<40$ yrs age & $\begin{array}{c}-0.00283 \\
(0.10) \\
{[47256]}\end{array}$ & $\begin{array}{c}0.0695 \\
(1.25) \\
{[28251]}\end{array}$ \\
\hline Head $>11$ yrs ed. & $\begin{array}{c}-0.0255 \\
(0.64) \\
{[44413]}\end{array}$ & $\begin{array}{c}0.152 \\
(2.00) \\
{[27758]}\end{array}$ \\
\hline Movers (in last five yrs) & $\begin{array}{c}0.0303 \\
(1.10) \\
{[57301]}\end{array}$ & $\begin{array}{c}0.0737 \\
(1.44) \\
{[33665]}\end{array}$ \\
\hline
\end{tabular}

Notes: z-statistics based on robust standard errors are in parentheses. The number of observations is in square brackets. The mean value of the dependent variable is in curved brackets. See notes to table 3 for descriptions of state-groups. The regressions control for the household head's age (quartic), years 
of education (quadratic), marital status, sex, veteran status, and migrant status (whether changed states in last five years), as well as the household's number of members (quadratic), number of children (series of indicators), and log family income (adjusted to 1969 dollars; plus a dummy for top-coded income). As discussed in the text, the availability of the suburban/central city distinction is compromised in some places for reasons of confidentiality. See Ruggles and Sobek (1997) for a detailed description of this issue. "Movers" are household heads living in a residence that is different from the one they lived in five years earlier.

Sources: Micro-level census data are from the IPUMS for 1960 and 1970 (Ruggles and Sobek 1997). 
Table 7: Metropolitan Area Segregation and Fair Housing Laws, 1960-1970

\begin{tabular}{lcc}
\hline Non-Experimental Group & With Group A & With Group B \\
\hline Fair Housing & 0.00185 & 0.00619 \\
& $(0.28)$ & $(0.50)$ \\
Ln Growth in Nonwhite Population & -0.0756 & -0.0785 \\
& $(3.00)$ & $(2.35)$ \\
Ln Growth in White Population & 0.000369 & 0.00614 \\
& $(0.01)$ & $(0.09)$ \\
Constant & 0.0117 & 0.00830 \\
& $(1.35)$ & $(0.63)$ \\
\hline Mean Dependent Variable & -0.0145 & -0.0184 \\
& $(0.0300)$ & $(0.0323)$ \\
$\mathrm{R}^{2}$ & 0.16 & 0.16 \\
Metro Areas & 70 & 49 \\
\hline
\end{tabular}

Notes: The dependent variable is the change in a dissimilarity index calculated on a white/nonwhite basis (1970 value - 1960 value). The samples include metropolitan areas available in both the 1960 and 1970 census tract data with tracts excluded if they were added to the metro area in 1970 (usually, additional suburban tracts). Also, only tracts falling within the set of states used throughout the paper are included. Metro areas with fewer than 1,000 nonwhite residents in 1960 are not included. Observations are weighted by 1960 total population. The fair housing coefficients change somewhat if the cities are unweighted, but they remain far from statistical and economic significance. t-statistics are in parentheses.

Sources: Census tract data were extracted from ICPSR studies 7552 (1960 census), 9014 (1970 fourth count population summary tape), and 8126 (1970 fourth count housing summary tape). 
Table 8: Census Tract Racial Composition, Property Values, and Fair Housing Laws, 1960-1970

\begin{tabular}{lcc}
\hline Non-Experimental Group & With Group A & With Group B \\
\hline Panel A: All Tracts, Racial Composition & & \\
Very White (> 0.99) & -0.0208 & -0.000183 \\
& $(1.58)$ & $(0.01)$ \\
Mean Dependent Variable & 0.521 & 0.489 \\
Number of Tracts & 25451 & 17430 \\
Number of Metro Areas & 77 & 52 \\
\hline Mostly Nonwhite (> 0.50) & -0.0111 & 0.00921 \\
& $(1.42)$ & $(0.73)$ \\
Mean Dependent Variable & 0.0979 & 0.0947 \\
Number of Tracts & 25451 & 17430 \\
Number of Metro Areas & 77 & 52 \\
\hline
\end{tabular}

Panel B: High Human Capital Tracts, Proportion Nonwhite

Nonwhite Proportion of

$-0.000300$

$-0.00166$

Population

(0.06)

$(0.21)$

Mean Dependent Variable

0.0364

0.0387

Number of Tracts

12637

9071

Number of Metro Areas

77

52

\section{Panel C: All Tracts, Property Value}

Value

0.00680

0.0360

$(0.21)$

(0.84)

Number of Tracts

23649

16007

Number of Metro Areas

77

52

\section{Panel D: All Tracts, Rent}

Rent

$-0.0162$

$-0.0359$

Number of Tracts

24778

16910

Number of Metro Areas

77

52 
Notes: In Panel A: the "very white" row reports results from an OLS regression in which the dependent variable equals one if the white proportion of the tract's population is over 0.99 ; the "mostly nonwhite" row reports results from an OLS regression in which the dependent variable equals one if the nonwhite proportion of the tract's population is over 0.50. The regressions include metro-area fixed effects, the proportion of the area's population that was nonwhite in each year, a 1970 dummy variable, and the interaction of the 1970 dummy and a dummy for fair-housing states. The table reports the coefficient on the interaction of fair-housing status and the 1970 dummy variable. In Panel B: the dependent variable is the nonwhite proportion of each tract's population; in this case, the sample consists only of census tracts in which the proportion of adults (over 24 years old) with at least twelve years of education was above the median for tracts in that year (based on tracts from the experimental states and both non-experimental groups); in 1960, the median tract's proportion of adults with twelve years of education was 0.391 ; in 1970 , the median proportion was 0.511 . The regressions include metropolitan area-specific fixed effects, the nonwhite proportion of the metro area's adult population with at least twelve years of schooling, the nonwhite proportion of the metro area's population, a 1970 dummy variable, and the interaction of the 1970 dummy and a dummy for fair-housing states. The table reports the coefficient on the interaction of fair-housing status and the 1970 dummy variable. In Panel $\mathrm{C}$ : the log of average property value or monthly gross rent is regressed on metro area fixed effects, $\log$ of metro area population, a dummy variable for mostly nonwhite tracts, a 1970 dummy variable, an interaction of the mostly nonwhite and 1970 variables, an interaction of the mostly nonwhite variable and a dummy for experimental states, an interaction of the experimental and 1970 dummies, and (reported in table) an interaction of the 1970 dummy, the dummy for experimental states, and the dummy for mostly nonwhite tracts. Throughout table 8, the 1970 census tract data are reported only for those with at least 25 residents, and so the 1960 sample is conditioned accordingly. Observations in Panel A are unweighted. Observations in Panel B, C, and D are weighted by tract population. tstatistics are in parentheses.

Sources: Census tract data were extracted from ICPSR studies 7552 (1960 census), 9014 (1970 fourth count population summary tape), and 8126 (1970 fourth count housing summary tape). 
Appendix Table A1: Fair Housing Laws and Housing Outcomes, Renters and Owners in Same Sample, 1960-1970

\begin{tabular}{|c|c|c|c|c|c|c|c|c|}
\hline \multirow[b]{2}{*}{ Non-Exp. State Group } & \multicolumn{2}{|c|}{ Rooms (OLS) } & \multicolumn{2}{|c|}{ Two Baths (Probit) } & \multicolumn{2}{|c|}{ Old Building (Probit) } & \multicolumn{2}{|c|}{ Suburb (Probit) } \\
\hline & $A$ & B & A & B & $A$ & B & $A$ & $\mathrm{~B}$ \\
\hline \multicolumn{9}{|l|}{ Owners and Renters } \\
\hline All households & $\begin{array}{l}-0.270 \\
(7.23)\end{array}$ & $\begin{array}{l}-0.178 \\
(3.47)\end{array}$ & $\begin{array}{c}-0.0004 \\
(0.04)\end{array}$ & $\begin{array}{l}0.005 \\
(0.35)\end{array}$ & $\begin{array}{l}0.023 \\
(1.57)\end{array}$ & $\begin{array}{c}-0.012 \\
(0.62)\end{array}$ & $\begin{array}{l}0.027 \\
(1.49)\end{array}$ & $\begin{array}{l}0.049 \\
(1.51)\end{array}$ \\
\hline $\begin{array}{l}\text { All households, w/ state and } \\
\text { state-year dummies }\end{array}$ & $\begin{array}{l}-0.265 \\
(7.19)\end{array}$ & $\begin{array}{l}-0.184 \\
(3.61)\end{array}$ & $\begin{array}{l}0.001 \\
(0.11)\end{array}$ & $\begin{array}{l}0.004 \\
(0.31)\end{array}$ & $\begin{array}{l}0.002 \\
(0.16)\end{array}$ & $\begin{array}{c}-0.039 \\
(2.00)\end{array}$ & $\begin{array}{l}0.020 \\
(1.05)\end{array}$ & $\begin{array}{l}0.027 \\
(0.75)\end{array}$ \\
\hline $\begin{array}{l}\text { All households, w/ prop. blk } \\
\text { and blk } \times \text { prop. blk }\end{array}$ & $\begin{array}{l}-0.190 \\
(5.09)\end{array}$ & $\begin{array}{l}-0.166 \\
(3.23)\end{array}$ & $\begin{array}{l}0.003 \\
(0.25)\end{array}$ & $\begin{array}{l}0.005 \\
(0.35)\end{array}$ & $\begin{array}{l}0.029 \\
(1.97)\end{array}$ & $\begin{array}{c}-0.018 \\
(0.93)\end{array}$ & $\begin{array}{l}0.010 \\
(0.52)\end{array}$ & $\begin{array}{l}0.007 \\
(0.22)\end{array}$ \\
\hline Head $<40$ yrs age & $\begin{array}{l}-0.234 \\
(4.65)\end{array}$ & $\begin{array}{l}-0.111 \\
(1.54)\end{array}$ & $\begin{array}{l}0.002 \\
(0.17)\end{array}$ & $\begin{array}{l}0.002 \\
(0.09)\end{array}$ & $\begin{array}{l}0.068 \\
(3.39)\end{array}$ & $\begin{array}{l}0.057 \\
(2.10)\end{array}$ & $\begin{array}{c}-0.000008 \\
(0.000)\end{array}$ & $\begin{array}{l}0.024 \\
(0.48)\end{array}$ \\
\hline Head $>11$ yrs educ & $\begin{array}{l}-0.227 \\
(3.47)\end{array}$ & $\begin{array}{c}-0.140 \\
(1.46)\end{array}$ & $\begin{array}{l}0.023 \\
(0.94)\end{array}$ & $\begin{array}{l}0.011 \\
(0.33)\end{array}$ & $\begin{array}{l}0.011 \\
(0.45)\end{array}$ & $\begin{array}{l}0.013 \\
(0.38)\end{array}$ & $\begin{array}{c}-0.066 \\
(2.01)\end{array}$ & $\begin{array}{l}0.046 \\
(0.81)\end{array}$ \\
\hline Movers & $\begin{array}{c}-0.224 \\
(4.64)\end{array}$ & $\begin{array}{c}-0.103 \\
(1.53)\end{array}$ & $\begin{array}{l}0.021 \\
(1.47)\end{array}$ & $\begin{array}{l}0.013 \\
(0.70)\end{array}$ & $\begin{array}{l}0.014 \\
(0.76)\end{array}$ & $\begin{array}{l}-0.017 \\
(0.068)\end{array}$ & $\begin{array}{l}0.023 \\
(0.93)\end{array}$ & $\begin{array}{l}-0.019 \\
(0.42)\end{array}$ \\
\hline
\end{tabular}

Notes: t-statistics (OLS) or z-statistics (probit) are in parentheses. See the notes to tables 4 and 6 for full descriptions of the variables and regression specifications.

Sources: Household data are from the IPUMS (Ruggles and Sobek, 1997). 
Appendix Table A2: Summary Statistics of Outcome Variables for Household Data

\begin{tabular}{|c|c|c|c|c|c|c|c|c|c|c|c|c|}
\hline \multirow[b]{2}{*}{ State Group } & \multicolumn{6}{|c|}{ 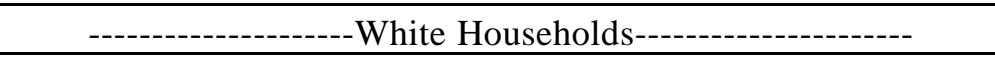 } & \multicolumn{6}{|c|}{ 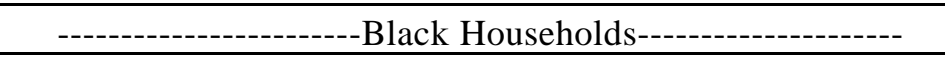 } \\
\hline & Exp. & Exp. & $\begin{array}{l}\text { Non- } \\
\text { Exp. A }\end{array}$ & $\begin{array}{l}\text { Non- } \\
\text { Exp. A }\end{array}$ & $\begin{array}{l}\text { Non- } \\
\text { Exp. B }\end{array}$ & $\begin{array}{l}\text { Non- } \\
\text { Exp. B }\end{array}$ & Exp. & Exp. & $\begin{array}{l}\text { Non- } \\
\text { Exp. A }\end{array}$ & $\begin{array}{l}\text { Non- } \\
\text { Exp. A }\end{array}$ & $\begin{array}{l}\text { Non- } \\
\text { Exp. B }\end{array}$ & $\begin{array}{l}\text { Non- } \\
\text { Exp. B }\end{array}$ \\
\hline Year & 1960 & 1970 & 1960 & 1970 & 1960 & 1970 & 1960 & 1970 & 1960 & 1970 & 1960 & 1970 \\
\hline \multicolumn{13}{|c|}{ All Households, Owners and Renters } \\
\hline Ownership & 0.61 & 0.65 & 0.67 & 0.69 & 0.66 & 0.68 & 0.27 & 0.31 & 0.32 & 0.38 & 0.39 & 0.40 \\
\hline Household & 3.63 & 3.57 & 3.66 & 3.61 & 3.64 & 3.52 & 3.67 & 3.57 & 3.82 & 3.73 & 4.08 & 3.90 \\
\hline Size & {$[1.71]$} & {$[1.80]$} & {$[1.72]$} & {$[1.78]$} & {$[1.75]$} & {$[1.74]$} & {$[2.28]$} & [2.16] & {$[2.32]$} & {$[2.21]$} & [2.61] & [2.29] \\
\hline \multicolumn{13}{|l|}{ Owners } \\
\hline Two Baths & 0.12 & 0.22 & 0.10 & 0.19 & 0.13 & 0.25 & 0.086 & 0.14 & 0.068 & 0.13 & 0.060 & 0.15 \\
\hline Old Building & 0.35 & 0.33 & 0.40 & 0.36 & 0.30 & 0.27 & 0.59 & 0.51 & 0.74 & 0.62 & 0.59 & 0.48 \\
\hline Rooms & $\begin{array}{c}5.78 \\
{[1.40]}\end{array}$ & $\begin{array}{c}6.08 \\
{[1.45]}\end{array}$ & $\begin{array}{c}5.72 \\
{[1.33]}\end{array}$ & $\begin{array}{c}5.95 \\
{[1.35]}\end{array}$ & $\begin{array}{c}5.55 \\
{[1.35]}\end{array}$ & $\begin{array}{c}5.88 \\
{[1.43]}\end{array}$ & $\begin{array}{c}5.88 \\
{[1.44]}\end{array}$ & $\begin{array}{c}5.87 \\
{[1.45]}\end{array}$ & $\begin{array}{c}5.89 \\
{[1.46]}\end{array}$ & $\begin{array}{c}6.04 \\
{[1.32]}\end{array}$ & $\begin{array}{c}5.51 \\
{[1.50]}\end{array}$ & $\begin{array}{c}5.86 \\
{[1.41]}\end{array}$ \\
\hline Hedonic Index & $\begin{array}{c}9.70 / 9.66 \\
{[0.39] /[0.38]}\end{array}$ & $\begin{array}{c}9.77 / 9.74 \\
{[0.39] /[0.40]}\end{array}$ & $\begin{array}{c}9.64 \\
{[0.40]}\end{array}$ & $\begin{array}{c}9.71 \\
{[0.41]}\end{array}$ & $\begin{array}{c}9.61 \\
{[0.46]}\end{array}$ & $\begin{array}{c}9.74 \\
{[0.45]}\end{array}$ & $\begin{array}{c}9.37 / 9.34 \\
{[0.29] /[0.29]}\end{array}$ & $\begin{array}{c}9.43 / 9.39 \\
{[0.25] /[0.23]}\end{array}$ & $\begin{array}{c}9.28 \\
{[0.30]}\end{array}$ & $\begin{array}{c}9.37 \\
{[0.25]}\end{array}$ & $\begin{array}{c}9.18 \\
{[0.39]}\end{array}$ & $\begin{array}{c}9.35 \\
{[0.34]}\end{array}$ \\
\hline Suburban & 0.65 & 0.71 & 0.65 & 0.72 & 0.59 & 0.70 & 0.16 & 0.17 & 0.18 & 0.18 & 0.25 & 0.32 \\
\hline \multicolumn{13}{|l|}{ Renters } \\
\hline Two Baths & 0.023 & 0.044 & 0.022 & 0.042 & 0.026 & 0.064 & 0.010 & 0.021 & 0.014 & 0.027 & 0.017 & 0.039 \\
\hline Old Building & 0.68 & 0.58 & 0.70 & 0.58 & 0.54 & 0.44 & 0.75 & 0.64 & 0.79 & 0.65 & 0.73 & 0.59 \\
\hline Rooms & $\begin{array}{c}4.23 \\
{[1.50]}\end{array}$ & $\begin{array}{c}4.23 \\
{[1.51]}\end{array}$ & $\begin{array}{c}4.41 \\
{[1.57]}\end{array}$ & $\begin{array}{c}4.46 \\
{[1.54]}\end{array}$ & $\begin{array}{c}4.23 \\
{[1.51]}\end{array}$ & $\begin{array}{c}4.43 \\
{[1.44]}\end{array}$ & $\begin{array}{c}3.94 \\
{[1.59]}\end{array}$ & $\begin{array}{c}4.10 \\
{[1.41]}\end{array}$ & $\begin{array}{c}3.94 \\
{[1.57]}\end{array}$ & $\begin{array}{c}4.38 \\
{[1.47]}\end{array}$ & $\begin{array}{c}4.00 \\
{[1.48]}\end{array}$ & $\begin{array}{c}4.53 \\
{[1.46]}\end{array}$ \\
\hline Hedonic Index & $\begin{array}{c}4.36 / 4.33 \\
{[0.25] /[0.26]}\end{array}$ & $\begin{array}{c}4.43 / 4.41 \\
{[0.26] /[0.27]}\end{array}$ & $\begin{array}{c}4.30 \\
{[0.27]}\end{array}$ & $\begin{array}{c}4.42 \\
{[0.28]}\end{array}$ & $\begin{array}{c}4.26 \\
{[0.34]}\end{array}$ & $\begin{array}{c}4.43 \\
{[0.33]}\end{array}$ & $\begin{array}{c}4.33 / 4.26 \\
{[0.12] /[0.15]}\end{array}$ & $\begin{array}{c}4.36 / 4.29 \\
{[0.10] /[0.11]}\end{array}$ & $\begin{array}{c}4.31 \\
{[0.14]}\end{array}$ & $\begin{array}{c}4.37 \\
{[0.10]}\end{array}$ & $\begin{array}{c}4.18 \\
{[0.21]}\end{array}$ & $\begin{array}{c}4.28 \\
{[0.16]}\end{array}$ \\
\hline Suburban & 0.27 & 0.35 & 0.38 & 0.50 & 0.29 & 0.51 & 0.066 & 0.079 & 0.090 & 0.101 & 0.12 & 0.14 \\
\hline
\end{tabular}

Notes: Mean values from "All Households" samples are reported, with standard deviations for non-binary variables in brackets. For the experimental states, two figures for the hedonic indices are reported because the hedonic index is formed first using the experimental states and non-experimental group A, and then using the experimental states and non-experimental group B. The changes over time are very similar with the different sets of hedonic weights. See the notes to tables $3,4,5$, and 6 for more details regarding the variables and 
samples.

Source: Household level data from the IPUMS (Ruggles and Sobek, 1997). 
Appendix Table A3: Summary Statistics of Outcome Variables for Census Tract Data

\begin{tabular}{|c|c|c|c|c|c|c|}
\hline State Group & Experimental & Experimental & Non-Exp. A & Non-Exp. A & Non-Exp. B & Non-Exp. B \\
\hline Year & 1960 & 1970 & 1960 & 1970 & 1960 & 1970 \\
\hline Very White Tracts & 0.58 & 0.43 & 0.60 & 0.49 & 0.53 & 0.35 \\
\hline Mostly Nonwhite Tracts & 0.069 & 0.11 & 0.091 & 0.13 & 0.11 & 0.13 \\
\hline $\begin{array}{l}\text { Nonwhite Prop. of High Human } \\
\text { Capital Tracts }\end{array}$ & $\begin{array}{l}0.028 \\
{[0.09]}\end{array}$ & $\begin{array}{l}0.043 \\
{[0.12]}\end{array}$ & $\begin{array}{l}0.030 \\
{[0.12]}\end{array}$ & $\begin{array}{l}0.044 \\
{[0.14]}\end{array}$ & $\begin{array}{l}0.042 \\
{[0.11]}\end{array}$ & $\begin{array}{l}0.064 \\
{[0.14]}\end{array}$ \\
\hline \multicolumn{7}{|l|}{ Property Value } \\
\hline Mostly Nonwhite & $\begin{array}{c}9.37 \\
{[0.38]}\end{array}$ & $\begin{array}{c}9.58 \\
{[0.37]}\end{array}$ & $\begin{array}{c}9.29 \\
{[0.46]}\end{array}$ & $\begin{array}{c}9.44 \\
{[0.41]}\end{array}$ & $\begin{array}{c}9.00 \\
{[0.29]}\end{array}$ & $\begin{array}{c}9.15 \\
{[0.35]}\end{array}$ \\
\hline Mostly White & $\begin{array}{c}9.63 \\
{[0.39]}\end{array}$ & $\begin{array}{c}10.02 \\
{[0.40]}\end{array}$ & $\begin{array}{c}9.56 \\
{[0.41]}\end{array}$ & $\begin{array}{c}9.88 \\
{[0.43]}\end{array}$ & $\begin{array}{c}9.48 \\
{[0.40]}\end{array}$ & $\begin{array}{c}9.85 \\
{[0.47]}\end{array}$ \\
\hline \multicolumn{7}{|l|}{ Rental Price } \\
\hline Mostly Nonwhite & $\begin{array}{c}4.26 \\
{[0.21]}\end{array}$ & $\begin{array}{c}4.67 \\
{[0.20]}\end{array}$ & $\begin{array}{c}4.29 \\
{[0.27]}\end{array}$ & $\begin{array}{c}4.66 \\
{[0.21]}\end{array}$ & $\begin{array}{c}4.20 \\
{[0.25]}\end{array}$ & $\begin{array}{c}4.61 \\
{[0.24]}\end{array}$ \\
\hline Mostly White & $\begin{array}{c}4.45 \\
{[0.28]}\end{array}$ & $\begin{array}{c}4.93 \\
{[0.29]}\end{array}$ & $\begin{array}{c}4.45 \\
{[0.30]}\end{array}$ & $\begin{array}{c}4.87 \\
{[0.29]}\end{array}$ & $\begin{array}{c}4.49 \\
{[0.30]}\end{array}$ & $\begin{array}{c}4.95 \\
{[0.30]}\end{array}$ \\
\hline
\end{tabular}

Notes: Mean values are reported for the "all household" samples. The proportion of "very white" and "mostly nonwhite" tracts are not weighted; the other variables are weighted by tract population. Standard deviations for non-binary variables are in brackets. See the notes to table 8 for full descriptions of the variables and sample.

Sources: The census tract data were extracted from ICPSR studies 7552 (1960 census), 9014 (1970 fourth count population summary tape), and 8126 (1970 fourth count housing summary tape). 